\title{
A Novel Regulatory Role of HrpD6 in Regulating hrp-hrc-hpa Genes in Xanthomonas oryzae pv. oryzicola
}

\author{
Yu-Rong Li, ${ }^{1}$ Hua-Song Zou, ${ }^{1}$ Yi-Zhou Che, ${ }^{2}$ Yi-Ping Cui, ${ }^{2}$ Wei Guo, ${ }^{2}$ Li-Fang Zou, ${ }^{1}$ Subhadeep Chatterjee, ${ }^{3}$ \\ Eulandria M. Biddle, ${ }^{4}$ Ching-Hong Yang, ${ }^{4}$ and Gong-You Chen ${ }^{1,2}$ \\ ${ }^{1}$ School of Agriculture and Biology, Shanghai Jiaotong University/Key Laboratory of Urban (South) by Ministry of Agriculture, \\ Shanghai, 200240, China; ${ }^{2}$ College of Plant Protection, Nanjing Agricultural University/Key Laboratory of Integrated \\ Management of Crop Diseases and Pests, Ministry of Education of China, Nanjing, 210095, China; ${ }^{3}$ Centre for DNA \\ Fingerprinting and Diagnostics, Hyderabad, 500 001, India; ${ }^{4}$ Department of Biological Sciences, University of Wisconsin- \\ Milwaukee 53211, U.S.A.
}

Submitted 11 September 2010. Accepted 11 May 2011.

Xanthomonas oryzae pv. oryzicola, the causal agent of bacterial leaf streak in the model plant rice, possesses a hypersensitive response and pathogenicity (hrp), hrp-conserved (hrc), hrp-associated (hpa) cluster (hrp-hrc-hpa) that encodes a type III secretion system (T3SS) through which T3SS effectors are injected into host cells to cause disease or trigger plant defenses. Mutations in this cluster usually abolish the bacterial ability to cause hypersensitive response in nonhost tobacco and pathogenicity in host rice. In Xanthomonas spp., these genes are generally assumed to be regulated by the key master regulators HrpG and HrpX. However, we present evidence that, apart from HrpG and HrpX, HrpD6 is also involved in regulating the expression of $h r p$ genes. Interestingly, the expression of hpa 2, hpa1, hpaB, hrcC, and $h r c T$ is positively controlled by HrpD6. Transcriptional expression assays demonstrated that the expression of the $h r c C, h r p D 5, h r p E$, and $h p a 3$ genes was not completely abolished by $h r p G$ and $h r p X$ mutations. As observed in analysis of their corresponding mutants, HrpG and HrpX exhibit contrasting gene regulation, particularly for $h p a 2$ and $h r c T$. Other two-component system regulators (Zur, LrpX, ColR/S, and Trh) did not completely inhibit the expression of $h r c C, h r p D 5, h r p E$, and hpa3. Immunoblotting assays showed that the secretion of HrpF, which is an HpaB-independent translocator, is not affected by the mutation in hrpD6. However, the mutation in hrpD6 affects the secretion of an HpaB-dependent TAL effector, AvrXa27. These novel findings suggest that, apart from HrpG and HrpX, HrpD6 plays important roles not only in the regulation of hrp genes but also in the secretion of TAL effectors.

Encoded by the hypersensitive response and pathogenicity ( $h r p$ ) genes, the type III secretion system (T3SS) delivers numerous T3SS effectors from plant-pathogenic bacteria into plant cells to cause diseases in susceptible host plants and to

Y.-R. Li and H.-S. Zou contributed equally to this work.

Corresponding author: G.-Y. Chen; Telephone: +86-021-3420-5873; Fax: +86-021-3420-5873; E-mail: gyouchen@ sjtu.edu.cn

* The $\boldsymbol{e}$-Xtra logo stands for "electronic extra" and indicates that three supplementary tables and two supplementary figures are published online. trigger a hypersensitive response (HR) in nonhost plants or resistant host plants (Alfano and Collmer 1997; Bonas 1994; Cunnac et al. 2009; Gürlebeck et al. 2006; He 1998; Hueck 1998). In xanthomonads, the hrp-hrc-hpa genes are highly conserved and clustered within the genome (Alfano and Collmer 1997; Bonas et al. 1991; Kim et al. 2003; Niño-Liu and Bogdanove 2006; Zou et al. 2006). The elucidation of the hrp-hrc-hpa cluster in Xanthomonas oryzae pv. oryzicola RS105 (Zou et al. 2006) and sequencing the complete genome of $X$. oryzae pv. oryzicola BLS256 (Niño-Liu and Bogdanove 2006) revealed that the core hrp cluster is composed of $10 \mathrm{hrp}$, 9 hrp-conserved ( $h r c$ ), and 8 hrp-associated (hpa) genes, which is similar in organization in different $X$. oryzae pv. oryzae strains (Lee et al. 2005; Ochiai et al. 2005; Salzberg et al. 2008). However, in spite of the common synteny of hrp genes in two closely related Xanthomonas pathovars $(X$. oryzae pv. oryzae and $X$. oryzae pv. oryzicola), the latter has hrpE3, which is specific to X. oryzae pv. oryzicola and is homologous to hpaE in X. campestris pv. vesicatoria (Büttner et al. 2007).

Expression of the $h r p-h r c-h p a$ genes is highly regulated and is generally suppressed in rich media but induced in planta and in certain synthetic media which mimic conditions inside the host plant (Brito et al. 1999; Schulte and Bonas 1992; Wei et al. 2000; Xiao et al. 1992; Xiao et al. 2007). The detection of expression of $h r p$ genes is traditionally assessed by polar transposon insertions using the $\beta$-glucuronidase gus $A$ gene as a reporter (Wengelnik and Bonas 1996; Wengelnik et al. 1996a and $b$ ) but it is believed that polar insertional mutagenesis may interfere in the crosstalk involving intergenic regions and genes in the hrp operon or regulon (Ortiz-Martin et al. 2010a and $b$ ).

Typically, the expression of each hrp-hrc-hpa gene is controlled mainly by two key master regulators, HrpG and HrpX, whose genetic loci are distant from the hrp-hrc-hpa cluster on the chromosome in Xanthomonas spp. (Büttner and Bonas 2006; Kim et al. 2003; Tang et al. 2006; Weber et al. 2007; Zou et al. 2006). HrpG is predicted to be an OmpR family response regulator of two-component signal transduction systems and, presumably, perceives an environmental signal via an as-yet-unknown sensor kinase (Wengelnik et al. 1996a and b, 1999). HrpX is an AraC-type transcriptional activator (Wengelnik et al. 1996a and b) which forms a homodimer, a helix-turn-helix motif that interacts with each TTCGC of the 
plant-inducible promoter (PIP)-box (TTCGC-N ${ }_{15}$-TTCGC) in $h r p$ transcripts to activate transcription of hrp genes (Furutani et al. 2006). In X. campestris pv. vesicatoria, the causal agent of bacterial spot disease in pepper and tomato, HrpG and HrpX form a regulatory cascade in which $\operatorname{HrpG}$ regulates the expression of the $h r p A$ operon and $h r p X$. HrpX subsequently activates the expression of other PIP-box containing hrp operons ( $h r p B$ to $h r p F)$ (Wengelnik and Bonas 1996; Wengelnik et al. $1996 \mathrm{a}$ and b). Further investigation revealed that $h r c C$ expression is regulated both by HrpG and HrpX (Huang et al. 2009). Although the hrp clusters among Xanthomonas spp. are highly conserved (Büttner et al. 2003; Gürlebeck et al. 2006), very little information is available about the regulatory cascade controlling expression of the $h r p$ operons in different species or pathovars of Xanthomonas.

It has been shown that other regulatory genes may also be involved in the transcriptional regulation to the expression of $h r p G$ gene along with other $h r p$ genes. The $h r p G$ gene expression in $X$. oryzae pv. oryzae is repressed by multiple regulatory pathways, including the two-component system PhoP/Q (Lee et al. 2008), the H-NS protein XrvA (Feng et al. 2009), and Trh, which is a member of the GntR family of regulators (Tsuge et al. 2006). In $X$. campestris pv. campestris, expression of the $h r p C$ and $h r p E$ operons located in the $h r p$ cluster is controlled by the two-component regulatory system ColR/S, suggesting that various signal transduction pathways are involved in the regulation of hrp gene expression and that individual $h r p$ operons might be regulated by different two-component signaling transduction pathways (Zhang et al. 2008). Consistent with this finding is that several hrp genes from $X$. axonopodis pv. citri are induced in the minimal medium XVM2, whereas $h r p B 1$ is repressed (Astua-Monge et al. 2005). This indicates that there might also be pathovar-specific differences in hrp gene expression in Xanthomonas spp. (Seo et al. 2008). The Xanthomonas bacterial regulatory network controlling hrp expression has been reviewed recently by Büttner and Bonas (2010).

Recent studies have shown that other two-component regulatory systems influence the expression of hrp genes which, in turn, are fine tuned by several environmental factors. In $X$. oryzae pv. oryzae, PhoP, a member of the well-characterized PhoP/Q two-component bacterial signal transduction system, is involved in regulation of $h r p G$ expression in $X$. oryzae pv. oryzae in response to low $\mathrm{Ca}^{2+}$ concentration (Lee et al. 2008). LrpX, a putative leucine-rich protein, regulates the expression of hrp genes independently of the regulatory pathway for HrpG-HrpX in X. oryzae pv. oryzae (Islam et al. 2009). A recent report revealed that Zur, a zinc uptake regulator belonging to the Fur family of transcription factors, from $X$. campestris pv. campestris 8004, positively regulates expression of hrp genes, presumably via the transcriptional activator $\operatorname{HrpX}$ (Huang et al. 2009).

Although the coordinated expression of Xanthomonas hrphrc-hpa expression is orchestrated by multiple two-component systems and transcriptional regulators such as Trh, Clp, Zur, LrpX, and ColR/S, there is always a basal expression level of $h r p$ genes that is not influenced by these regulators. There is no evidence that an internal Hrp protein encoded by the hrphrc-hpa cluster has the ability to control hrp-hrc-hpa expression in Xanthomonas spp. In this study, we used the hrp-hrchpa cluster of a model plant-pathogenic bacterium $X$. oryzae pv. oryzicola, the causal agent of bacterial leaf streak disease in rice, to demonstrate that all of the hrp-hrc-hpa genes except hpa2, hrcC, hrcT, hrpD5, hrpE, and hpa3 are positively regulated in a coordinated fashion by HrpG and HrpX. The expression of hpa2 was positively regulated by HrpG but not by HrpX, and the expression of $h r c T$ was positively regulated by
HrpX but negatively regulated by HrpG. We also provide experimental evidence that the expression of hpa2, hpal, hpaB, $h r c C$, and $h r c T$ is positively controlled by HrpD6. The hrpD6 mutants are deficient in secretion of Hpa2, Hpa1, and HpaBdependent T3SS effectors, such as the TAL effector AvrXa27. This is the first report that the expression of $h r c C, h r p D 5, h r p E$, and hpa3 is HrpG- and HrpX-independent and the internal hrp gene product HrpD6 has the novel regulatory role in the expression of Hrp proteins and also is involved in the secretion of Hpa proteins and TAL effectors in Xanthomonas spp.

\section{RESULTS}

\section{Nonpolar mutations in the hrp system of $X$. oryzae pv. oryzicola.}

To precisely evaluate the expression profiles of the individual genes, $27 h r p$ - $h r c-h p a$ genes, 2 key $h r p$ regulatory genes ( $h r p G$ and $h r p X$ ) (Table 1; Fig. 1A), and 5 two-component system regulator genes (trh, zur, lrpX, colR, and colS) (Table 1; Supplementary Fig. S2) in X. oryzae pv. oryzicola RS105 were deleted individually by using vector pKMS 1 containing the $s a c B$ gene (Jiang et al. 2009). Two flanking fragments located at various distances upstream and downstream of the target genes were fused in pKMS1 (Table 1), and the deletions were obtained by $\mathrm{SacB} /$ sucrose counterselection (details below). Each mutation was confirmed by polymerase chain reaction (PCR) and Southern hybridization (data not shown). Based on pathogenicity assays in rice cv. IR24, which is susceptible to $X$. oryzae pv. oryzicola, and the ability to elicit HR response in nonhost tobacco cultivar Xanthi, the phenotypes (Fig. 1A) exhibited by the 26 hrp-hrc-hpa mutants (excluding hrpE3) and 2 key $h r p$ regulatory gene mutants, $h r p G$ and $h r p X$, were consistently similar to those caused by 26 hrp-hrc-hpa gene mutants and $h r p G$ and $h r p X$ mutants in $X$. oryzae pv. oryzae (Cho et al. 2008), the causal agent of bacterial blight in rice. A nonpolar mutation in the hrpE3 gene of $X$. oryzae pv. oryzicola, homologous to hpaE in X. campestris pv. vesicatoria (Büttner et al. 2007), led to reduced virulence in host rice but retained the ability to elicit HR in nonhost tobacco (Fig. 1A). These results indicate that $h r p$-hrc genes (except $h r p E 3$ ) in the $h r p$ cluster and $h r p G$ and $h r p X$ genes are essential for both the pathogenicity of $X$. oryzae pv. oryzicola in host rice and HR induction in nonhost tobacco. Disruption of hpa genes (except $h p a B$ ) had little effect on pathogenicity in rice and HR induction in tobacco but was deficient in virulence in comparison to the wild-type strain (Fig. 1A), suggesting that these hpa genes are required for full virulence of $X$. oryzae pv. oryzicola in rice. On the other hand, mutations in either the promoter of the $h r p B$ operon ( $p h r c T 1)$ or in the promoter of the $h r p D$ operon (phrpD51) (Table 1), which contains a PIP-box, resulted in loss of pathogenicity of $X$. oryzae pv. oryzicola in rice and HR induction in tobacco (data not shown).

Among the mutants with deletions in the zur, $\operatorname{lrp} X$, colR, cols, and trh genes (Table 1), only the colR mutant lost pathogenicity in rice. The remainder exhibited HR in tobacco but showed reduced virulence in rice. Homologs of $X$. oryzae pv. oryzae and $X$. campestris pv. campestris have been reported to cause delayed pathogenicity in host plants and HR in nonhost tobacco (Huang et al. 2009; Islam et al. 2009; Tang et al. 2005; Tsuge et al. 2006; Yang et al. 2007; Zhang et al. 2008).

\section{HrpG and HrpX exhibit differential regulatory roles in the expression of hrp-hrc-hpa genes in $X$. oryzae pv. oryzicola.}

Expression of the hrp-hrc-hpa genes is induced upon interaction of pathogenic Xanthomonas strains with host plants (Schulte and Bonas 1992; Zou et al. 2006). Though it has been considered that HrpG and HrpX regulate the expression of the 
hrp cluster, it is unclear whether these two regulators control the expression of all the hpa-hrp-hrc genes in Xanthomonas spp. Our previous report demonstrated that the $h r p$-inducing medium XOM3 (XOM2-modified medium) could induce hrp gene expression similar to that observed when the bacterium was co-cultured in rice suspension cells (Xiao et al. 2007). To mimic the growth conditions of $X$. oryzae pv. oryzicola in rice tissue, we used rice suspension cells to investigate whether the expression of all the hrp-hrc-hpa genes is regulated by HrpG and HrpX by reverse-transcription (RT)-PCR. After $16 \mathrm{~h}$ of interaction with rice suspension cells, 27 hpa-hrp-hrc genes and 2 regulatory genes ( $h r p G$ and $h r p X)$ were induced in the wild-type strain $X$. oryzae pv. oryzicola RS105 (Fig. 1B). However, in the $h r p G$ mutant $\mathrm{R} \Delta h r p G$, expression of $h r c C$, hrcT, hrpD5, hrpE, and hpa3 genes is still observed (Fig. 1B). The expression of $h p a 2, h r c C, h r p D 5, h r p E$, and $h p a 3$ was not completely attenuated in the $h r p X$ mutant $\mathrm{R} \Delta h r p X$ (Fig. 1B). This result indicates that the expression of $h r c T$ was positively regulated by $\operatorname{HrpX}$ but negatively regulated by HrpG. In contrast, hpa 2 expression was positively controlled by HrpG but not by HrpX. Comparison of hrp-hrc-hpa gene expression profiles in $h r p G$ and $h r p X$ mutants suggests that the expression of $h r c C$, hrpD5, hrpE, and hpa3 is partially HrpG and HrpX independent in $X$. oryzae pv. oryzicola.

\section{Genes with PIP-box promoters are induced under hrp-inducing conditions.}

In Xanthomonas spp., the expression of hrp-hrc-hpa genes is induced by the regulators $h r p G$ and $h r p X$ and it has been seen to be induced in nutrient-deficient media but repressed in nutrient-rich media (Tsuge et al. 2001; Wengelnik et al. 1996a and b; Xiao et al. 2007). The expression profiles of the $h r c C$, hrpD5, hrpE, and hpa3 genes which are partially HrpG and HrpX independent prompted us to investigate whether their promoters are possibly regulated by HrpX by searching for the presence of a PIP-box sequence using online software. The

Table 1. Strains and plasmids mainly used in this study

\begin{tabular}{|c|c|c|}
\hline Strains & Relevant characteristics $^{\mathbf{a}}$ & Source \\
\hline \multicolumn{3}{|l|}{ Escherichia coli } \\
\hline DH5 $\alpha$ & $\begin{array}{l}\mathrm{F}^{-} \text {- } 80 \mathrm{~d} \text { lacZ } \triangle \mathrm{M} 15 \Delta(\text { lacZYA-argF }) \mathrm{U} 169 \text { endA1 deoR recAl hsdR17 }\left(\mathrm{r}_{\mathrm{K}}^{-} \mathrm{m}_{\mathrm{K}}^{+}\right) \text {phoA supE44 } \\
\lambda^{-} \text {thi-l gyrA96 relA1 }\end{array}$ & $\begin{array}{l}\text { Clontech, Palo Alto, } \\
\text { CA, U.S.A. }\end{array}$ \\
\hline \multicolumn{3}{|c|}{ Xanthomonas oryzae pv. oryzicola } \\
\hline RS105 & Wild type, Chinese race 2 ; Rif $^{r}$ & Lab collection \\
\hline $\mathrm{R} \Delta h r p G$ & hrpG knock-out mutant of strain RS105, $792 \mathrm{bp}, 1$ to $792(-)$; Rif ${ }^{\mathrm{r}}$ & Jiang et al. 2009 \\
\hline $\mathrm{R} \Delta h r p X$ & hrpX knock-out mutant of strain RS105, $1,431 \mathrm{bp}, 1$ to $1431(+)$; Rif $^{\mathrm{r}}$ & Jiang et al. 2009 \\
\hline $\mathrm{R} \Delta h r c V$ & hrcV knock-out mutant of strain RS105,1,938 bp, 372 to $1920(+)$; $\operatorname{Rif}^{\mathrm{r}}$ & Wang et al. 2009 \\
\hline $\mathrm{R} \Delta h r p D 6$ & hrpD6 knock-out mutant of strain RS105, 243 bp, 1 to 243 (+); Rif $^{\mathrm{r}}$ & This work \\
\hline $\mathrm{R} \Delta h p a B$ & hpaB knock-out mutant of strain RS105, $471 \mathrm{bp}, 1$ to $471(+) ;$ Rif $^{\mathrm{r}}$ & This work \\
\hline $\mathrm{R} \Delta z u r$ & zur knock-out mutant of strain RS105, 507 bp, 60 to 465(+); Rif $^{\mathrm{r}}$ & This work \\
\hline $\mathrm{R} \Delta \operatorname{lrp} X$ & $\operatorname{lrp} X$ knock-out mutant of strain RS105, $1,959 \mathrm{bp}, 120$ to $1811(+)$; Rif ${ }^{\mathrm{r}}$ & This work \\
\hline $\mathrm{R} \Delta$ colR & colR knock-out mutant of strain RS105, $678 \mathrm{bp}, 73$ to $622(-)$; Rif $^{\mathrm{r}}$ & This work \\
\hline $\mathrm{R} \Delta \operatorname{col} S$ & cols knock-out mutant of strain RS105, $1,335 \mathrm{bp}, 85$ to $1172(-)$; Rif $\mathrm{r}$ & This work \\
\hline $\mathrm{R} \Delta t r h$ & trh knock-out mutant of strain RS105, 759 bp, 56 to $105(+) ;$ Rif $^{r}$ & This work \\
\hline $\mathrm{R} \Delta h r p D 51$ & phrpD51 knock-out mutant of strain RS105; Rif $^{\mathrm{r}}$ & This work \\
\hline $\mathrm{R} \Delta h r p D 52$ & phrpD52 knock-out mutant of strain RS105; Rif ${ }^{\mathrm{r}}$ & This work \\
\hline $\mathrm{CR} \Delta h r p D 6$ & $\mathrm{R} \Delta h r p D 6$ containing $\mathrm{pChrpD6} ; \mathrm{Sp}^{\mathrm{r}}$ & This work \\
\hline RS106(hrpD6) & RS105 containing pChrpD6; $\mathrm{Sp}^{\mathrm{r}}$ & This work \\
\hline $\mathrm{R} \Delta h r p X(\mathrm{pD} 6 \mathrm{hpa} 1 \mathrm{GUS})$ & $\mathrm{R} \Delta h r p X$ containing pD6hpa1GUS; Kan ${ }^{\mathrm{r}}$ & This work \\
\hline $\mathrm{R} \Delta h r p X(\mathrm{phpa} 1 \mathrm{GUS})$ & $\mathrm{R} \Delta h r p X$ containing phpa1GUS; $\mathrm{Kan}^{\mathrm{r}}$ & This work \\
\hline \multicolumn{3}{|c|}{ К } \\
\hline pKMS1 & $6.4 \mathrm{~kb}$, derivative from pK18mobGII, $s a c B^{+} ; \mathrm{Kan}^{\mathrm{r}}$ & Lab collection \\
\hline pHM1 & Broad-host range cos parA IncW derivative of pRI $40 ; \mathrm{Sp}^{\mathrm{r}}, \mathrm{Sm}^{\mathrm{r}}$ & Lab collection \\
\hline pKMS $\Delta h p a B$ & A $1,109-\mathrm{bp}$ fusion ligated in pKMS1 with a 471-bp deletion in $h p a B ; \mathrm{Kan}^{\mathrm{r}}$ & This work \\
\hline pKMS $\Delta z u r$ & A 934-bp fusion ligated in pKMS1 with a 406-bp deletion in zur; $\mathrm{Kan}^{\mathrm{r}}$ & This work \\
\hline pKMS $\Delta l r p X$ & A $1,026-b p$ fusion ligated in pKMS1 with a 1,692-bp deletion in $\operatorname{lrpX} ; \mathrm{Kan}^{\mathrm{r}}$ & This work \\
\hline $\mathrm{pKMS} \Delta \operatorname{col} R$ & A 865-bp fusion ligated in pKMS1 with a 550-bp deletion in $\operatorname{colR} ; \mathrm{Kan}^{\mathrm{r}}$ & This work \\
\hline $\mathrm{pKMS} \Delta \mathrm{col} S$ & A 732-bp fusion ligated in pKMS1 with a 1,088-bp deletion in cols; $\operatorname{Kan}^{\mathrm{r}}$ & This work \\
\hline pKMS $\Delta$ trh & A 837-bp fusion ligated in pKMS1 with a 450-bp deletion in trh; Kan ${ }^{\mathrm{r}}$ & This work \\
\hline pKMS $\triangle p h r p D 51$ & A 809-bp fusion ligated in pKMS1 with deletion in phrpD51; Kan ${ }^{\mathrm{r}}$ & This work \\
\hline pKMS $\triangle p h r p D 52$ & A 696-bp fusion ligated in pKMS1 with deletion in phrpD52; $\operatorname{Kan}^{\mathrm{r}}$ & This work \\
\hline pAvrXa27-FLAG & pHM1 expressing AvrXa27 under the control of lacZ promoter with a FLAG tag, Sp ${ }^{\mathrm{r}}$ & Gu et al. 2005 \\
\hline pHrpF-c-Myc & pHM1 expressing HrpF under the control of its own promoter with a c-Myc tag; $\mathrm{Sp}^{\mathrm{r}}$ & This work \\
\hline pHpa1-c-Myc & pHM1 expressing Hpa1 under the control of its own promoter with a c-Myc tag; $\mathrm{Sp}^{\mathrm{r}}$ & This work \\
\hline pHра2-c-Мус & pHM1 expressing Hpa2 under the control of its own promoter with a c-Myc tag; $\mathrm{Sp}^{\mathrm{r}}$ & This work \\
\hline pChrpD6 & pHM1 expressing $h r p D 6$ under the control of the $h r p D$ operon promoter; $\mathrm{Sp}^{\mathrm{r}}$ & This work \\
\hline pD6hpa1GUS & $\begin{array}{l}\text { pUFR034 expressing GUS under the promoter of } h p a l \text { with the } h r p D 6 \text { constitutively expressed; } \\
\operatorname{Kan}^{r}\end{array}$ & This work \\
\hline phrpGGUS & pUFR034 expressing GUS under the promoter of $h r p G ; \operatorname{Kan}^{\mathrm{r}}$ & This work \\
\hline phrpXGUS & pUFR034 expressing GUS under the promoter of $h r p X ; \mathrm{Kan}^{\mathrm{r}}$ & This work \\
\hline phpa3GUS & pUFR034 expressing GUS under the promoter of hpa $; \operatorname{Kan}^{\mathrm{r}}$ & This work \\
\hline phrcCGUS & pUFR034 expressing GUS under the promoter of $h r c C ; \operatorname{Kan}^{\mathrm{r}}$ & This work \\
\hline phrpD51GUS & pUFR034 expressing GUS under the promoter of $h r p D$ operon; $\operatorname{Kan}^{\mathrm{r}}$ & This work \\
\hline phrpD52GUS & pUFR034 expressing GUS under the predicted promoter region upstream of $h r p D 5 ; \operatorname{Kan}^{\mathrm{r}}$ & This work \\
\hline phrcT1GUS & pUFR034 expressing GUS under the promoter of $h r p B$ operon; $\operatorname{Kan}^{\mathrm{r}}$ & This work \\
\hline phrcT2GUS & pUFR034 expressing GUS under the predicted promoter region upstream of $h r c T ; \operatorname{Kan}^{\mathrm{r}}$ & This work \\
\hline phpa2GUS & pUFR034 expressing GUS under the promoter of $h p a 2 ; \operatorname{Kan}^{\mathrm{r}}$ & This lab \\
\hline phpa1GUS & pUFR034 expressing GUS under the promoter of hpal; $\mathrm{Kan}^{\mathrm{r}}$ & This work \\
\hline
\end{tabular}

\footnotetext{
${ }^{a}$ Length of the genes measure in base pairs (bp), and range indicates deleted position from site (bp) to site (bp) of the target open reading frames; $+=$ positive chain and $-=$ negative chain. Rif $^{\mathrm{r}}, \mathrm{Sp}^{\mathrm{r}}, \mathrm{Kan}^{\mathrm{r}}$, and $\mathrm{Sm}^{\mathrm{r}}$ indicate resistant to rifampin, kanamycin, spectinomycin, and streptomycin, respectively; GUS = $\beta$-glucuronidase.
} 
deduced promoters - phrcC for the $h r c C$ gene in $h r p A$ operon from -285 to -1 bp (no PIP-box sequence) upstream of the $h r c C$ open reading frame (ORF), phrcTl for the $h r p B$ operon from -177 to $155 \mathrm{bp}$ (with PIP-box sequence) overlap and upstream of the $h r p B 1$ gene, phrcT2 possible for the $h r c T$ gene from 1,200 to 1,427 bp (no PIP-box sequence) within the $h r c N$ gene, phrpD51 for the $h r p D$ operon from -606 to $-237 \mathrm{bp}$ (with PIP-box sequence) upstream of the $h r c Q$ gene, phrpD52 possible for the hrpD5 gene from 613 to 820 bp (no PIP-box sequence) within the hpaA gene and upstream of the hrpD5 gene, and phpa 3 for the hpa3 operon from -129 to 83 bp overlap and upstream of the hpa3 gene (Fig. 2A; Table 2)-were PCR amplified with the corresponding primers (Table 2) and cloned upstream from a promoterless gusA gene preceded by a termination codon in a reporter plasmid (Table 1). The plasmids were introduced into $X$. oryzae pv. oryzicola wild-type strain RS105, and each transformants were incubated in rice suspension cells, an hrp-inducing medium XOM3, and nutrient agar without agar (NB) nutrient-rich medium for $16 \mathrm{~h}$, respectively. Then, the $\beta$-glucuronidase (GUS) activity was
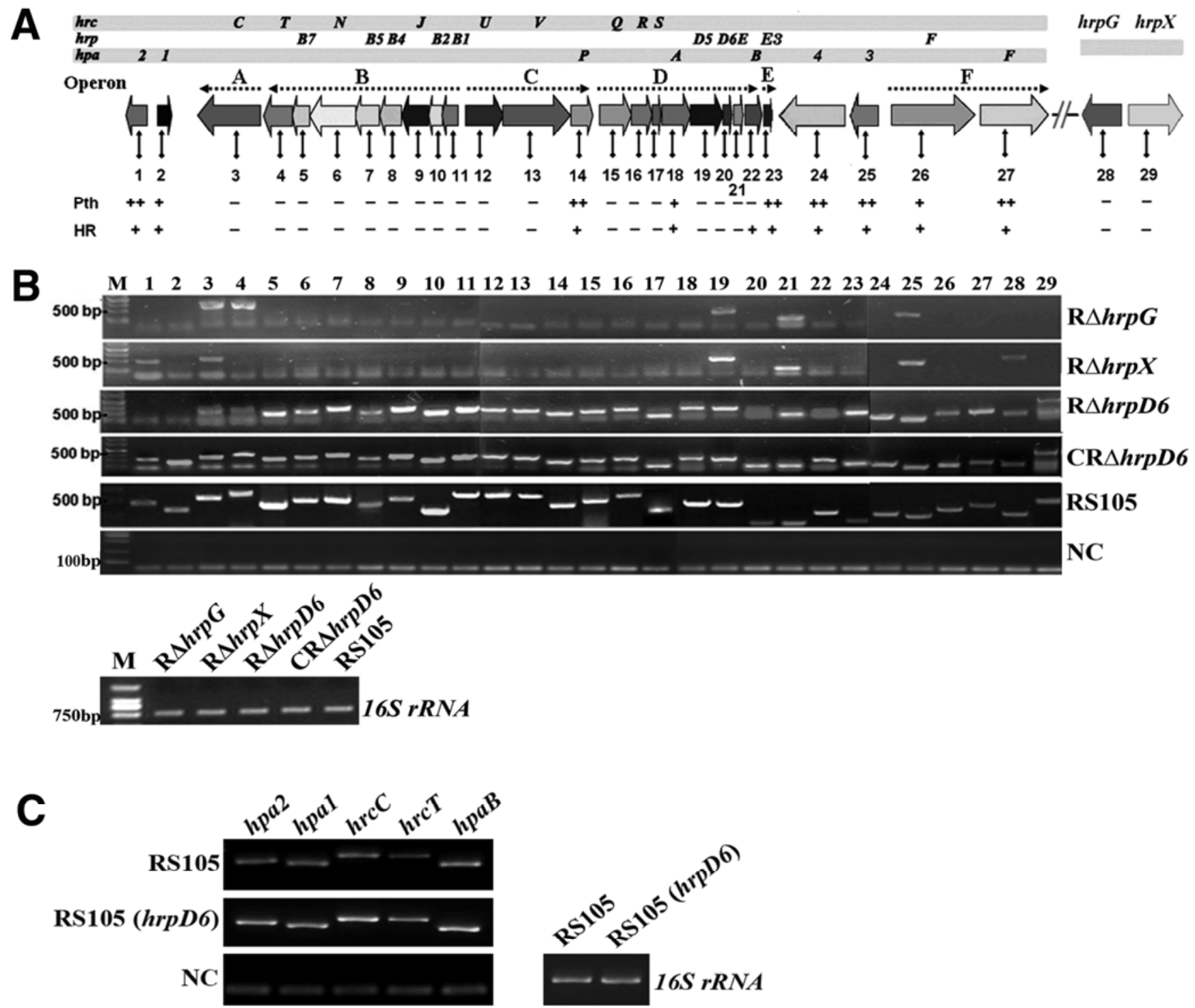

Fig. 1. Expression profiles of the hypersensitive response and pathogenicity $(h r p)$, $h r p$-conserved $(h r c)$, $h r p$-associated $(h p a)$ gene cluster $(h r p-h r c-h p a)$ of Xanthomonas oryzae pv. oryzicola in the $h r p G, h r p X$, and $h r p D 6$ mutant backgrounds. A, Genetic organization of 27 hrp-hrc-hpa genes and two key regulatory genes ( $h r p G$ and $H r p X)$ and their contribution to pathogenicity in susceptible host rice cv. IR24, and hypersensitive response (HR) induction in the nonhost tobacco cultivar Xanthi. Transcript units of these hrp-hrc-hpa genes are modified based on the reference (Zou et al. 2006) and the data in this report. Above the $h r p$ clusters, each gene is indicated correspondingly by $h r p, h r c$, and $h p a$. Below each $h r p-h r c-h p a$ gene, the vertical arrows display the deletion mutants achieved and numbered in this report. Under the numbers, the pathogenicity (Pth) in rice and HR in tobacco by each mutant are demonstrated by "+", "++", and "-"; + indicates that the mutants still triggered pathogenicity in rice and HR in tobacco similar to the wild-type strain RS105 and - means that the mutants lost the ability to trigger pathogenicity and HR in plants. The pathogenicity of each hrp mutant is represented as follows (mm refers to lesion length): -, no lesion formed; +, less than $5 \mathrm{~mm} ;++, 5$ to $10 \mathrm{~mm}$. As the control, the wild-type strain RS105 formed a 15-mm lesion length. B, Expression profiles of the $h r p$ - $h r c-h p a$ genes revealed at transcriptional level by semiquantitative reverse-transcription polymerase chain reaction (RT-PCR). C, HrpD6 overexpression increased the expression of $h p a 2, h p a 1, h r c C, h r c T$, and $h p a B$. RT-PCR was performed to assay the transcription levels of the tested genes in the wild-type RS105, the $h r p G$ mutant R $\Delta h r p G$, the $h r p X$ mutant R $\Delta h r p X$, the $h r p D 6$ mutant R $\Delta h r p D 6$, the complementation strain CR $\Delta h r p D 6$ of R $\Delta h r p D 6$ with the hrpD6 gene driven by the $h r p D$ operon promoter, and the $h r p D 6$ overexpression strain RS105 ( $r r p D 6$ ), grown in rice suspension cells for $16 \mathrm{~h}$, by using the primer pairs of the individual $h r p$ - $h r c-h p a$ genes of $X$. oryzae pv. oryzicola. In addition, the extracted RNAs were used for PCR to ensure that samples were free of DNA contamination as the negative control (NC) where only primer dimers formed. The PCR products were analyzed in $1.2 \%$ agarose gels. The $16 S$ $r R N A$ gene of the pathogen was used as the internal control to verify the absence of significant variation at the cDNA level in samples. Lanes numbered on the top of the gel match the numbers indicating each of the hrp genes. The experiment was repeated at least three times and similar results were obtained. 
measured by using $\rho$-nitrophenyl $\beta$-D-glucuronide (PNPG) as the substrate (Fig. 2B). The transformants harboring the predicted promoters, phrcC, phrcT1, phrpD51, and phpa3, exhibited significantly higher activity in both rice suspension cells and the $h r p$-inducing XOM3 compared with expression in NB medium ( $t$ test, $P=0.01$ ) (Fig. $2 \mathrm{~B}$ ), indicating that the transcription of the $h r c C$, hrcT, hrpD5, and hpa3 genes in $X$. oryzae pv. oryzicola is induced in hrp-inducing conditions and repressed in nutrient-rich medium. On the other hand, gus $A$ expression driven by the phrcT2 or the phrpD52 promoter was similar among cells induced in rice suspension cells, XOM3, or NB media (Fig. 2B).

Global regulators Trh, Zur, LrpX, and ColR/S have regulatory effects on the expression of $h r c C, h r p E, h r p G$, and $h r p X$ but not hrcT, hrpD5, and hpa3.

Previous reports showed that Trh transcriptionally activates $h r p G$ expression (Tsuge et al. 2006), and LrpX negatively regulates the transcripts of $h r p X$ and most $h r p$ operons in $X$. oryzae pv. oryzae (Islam et al. 2009). It is also known that, in $X$. campestris pv. campestris, Zur regulates the expression of the $h r p$-hrc-hpa cluster via $h r p X$ but not $h r p G$ (Huang et al. 2009), and ColR/S positively regulates expression of the $h r p C$ and $h r p E$ operons (Zhang et al. 2008). To see whether these regulators are involved in regulation of $h r p G, h r p X, h r c C$, $h r c T, h r p D 5, h r p E$, and $h p a 3$, we first generated $t r h, \operatorname{lrpX}, z u r$, colR, and colS deletions in X. oryzae pv. oryzicola using the suicide vector pKMS1 (Jiang et al. 2009), resulting in R $\Delta t r h$, $\mathrm{R} \Delta l r p X, \mathrm{R} \Delta z u r \mathrm{R} \Delta$ colR, and $\mathrm{R} \Delta$ cols mutants (Table 1), respectively. Subsequently, the reporter plasmids mentioned above were introduced into the mutant strains $\mathrm{R} \Delta h r p X$, $\mathrm{R} \Delta h r p G, \mathrm{R} \Delta z u r, \mathrm{R} \Delta l r p X, \mathrm{R} \Delta$ colR, $\mathrm{R} \Delta$ cols, and $\mathrm{R} \Delta t r h$. The GUS activities of the resulting reporter strains were measured after $16 \mathrm{~h}$ of growth in the $h r p$-inducing XOM3. The results indicated that $h r c C$ expression was downregulated in $\mathrm{R} \Delta h r p G$, $\mathrm{R} \Delta z u r, \mathrm{R} \Delta$ colR, and $\mathrm{R} \Delta t r h$ compared with the wild-type strain RS105 and strains R $\Delta h r p X, \mathrm{R} \Delta \operatorname{lrp} X$, and R $\Delta$ cols (Fig. 3).

In the case of the $h r p B$ operon, the GUS activity of phrcTl and $p h r c T 2$ was not significantly affected in these five global regulator mutant backgrounds and in the $\operatorname{hrp} G$ mutant, $\mathrm{R} \Delta h r p G$, whereas the GUS activity of $p h r c T 1$ was considerably ( $t$ test, $P=0.01$ ) reduced in the R $\Delta h r p X$ background (Fig. $3)$. This suggests that expression of the $h r p B$ operon, including the $h r c T$ gene, is positively regulated by $\operatorname{HrpX}$, and the mutations in hrpG, zur, lrpX, colR, colS, and trh have no effect on transcription of the $h r p B$ operon in $X$. oryzae pv. oryzicola. Additionally, no change in GUS activity was observed in any of the strains with mutations in these regulatory genes harboring phrpD52GUS whereas the GUS activity of phrpD51 was significantly decreased in the R $\Delta h r p X$ background (Fig. 3), which indicates that the $h r p D$ operon is possibly regulated by HrpX. In addition, hpa3 expression was not significantly affected in any of the mutants with deletions in the above regulatory genes (Fig. 3), suggesting that hpa3 expression is not controlled by HrpG, HrpX, Zur, LrpX, CorR, ColS, or Trh. On the other hand, the mutation in trh led to significantly lower GUS activity with the hrpG promoter, compared with that in other regulatory gene mutants and the wild type (Fig. 3C). This is consistent with the observation that Trh positively regulates the expression of $h r p G$ in $X$. oryzae pv. oryzae (Tsuge et
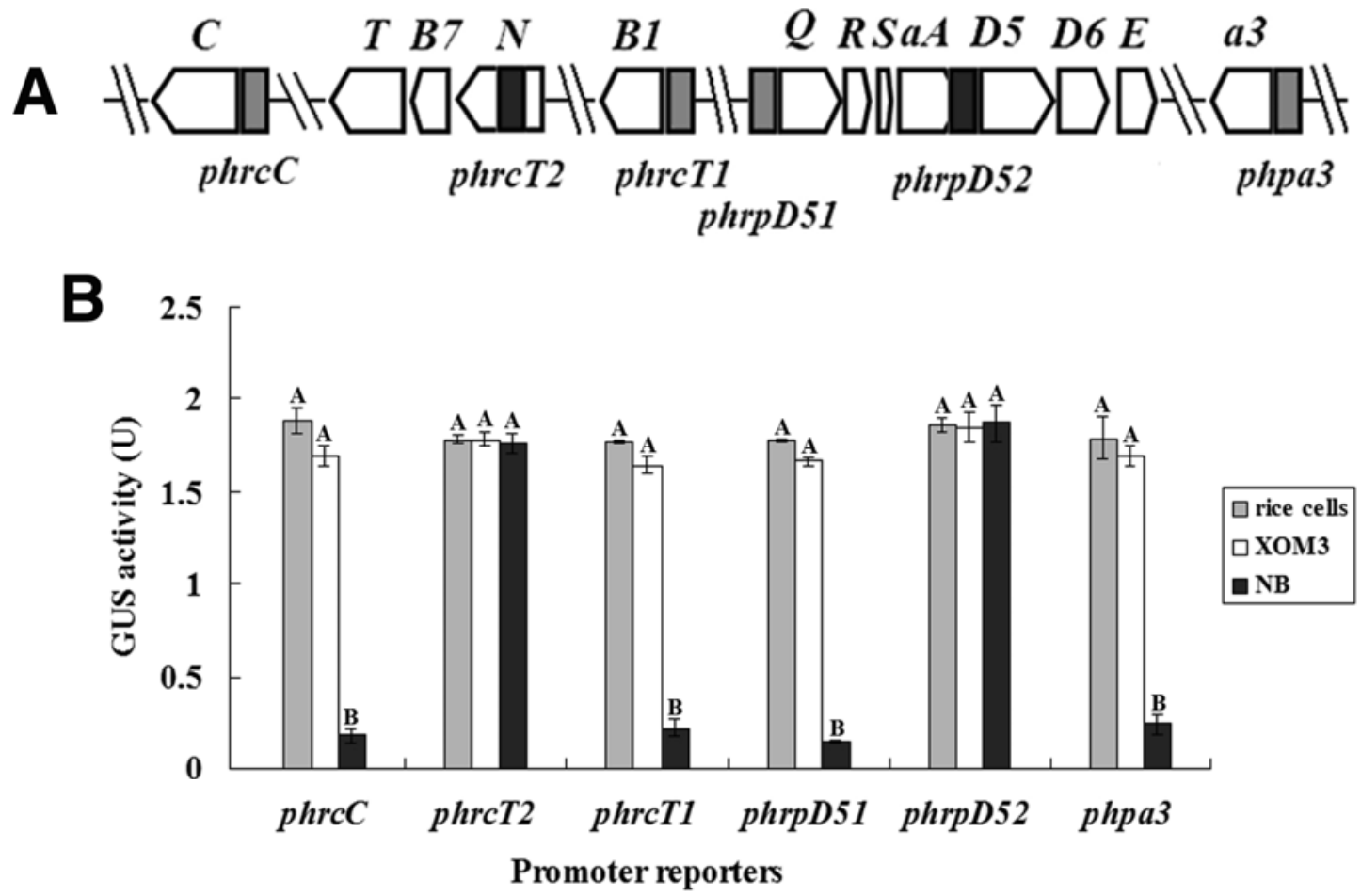

Fig. 2. Transcriptional organization and promoter location analysis of the hypersensitive response and pathogenicity ( $h r p) A$ operon for the $h r p$-conserved ( $h r c) C$ gene; the $h r p B$ operon from the $h r p B 1$ to $h r c T$ genes; the $h r p D$ operon for the $h r c Q, h r c R, h r c S, h r p$-associated $(h p a) A, h r p D 5, h r p D 6, h r p E$, and $h p a B$ genes; and an uncertain operon for $h p a 3$ gene in Xanthomonas oryzae pv. oryzicola. The locations of promoter regions in the hrp-hrc-hpa cluster from $h r p A$ to the uncertain hpa3 operon (containing hpa3 gene). Gray boxes, designated phrcC, phrcT1, phrpD51, and phpa3, indicate the promoters containing perfect or imperfect plant-inducible promoter-boxes (TTCGC-N ${ }_{15}$-TTCGC) (Zou et al. 2006). Black boxes represent the predicted promoters, phrcT2 within the $h r c N$ gene, and phrpD52 in the hpaA gene, analyzed by online software. $\beta$-Glucuronidase (GUS) activity of the $h r p$ promoter-gusA reporters in the wildtype RS105 of X. oryzae pv. oryzicola grown in rice suspension cells, hrp-inducing medium XOM3, and the nutrient-rich medium NB for 16 h were determined by measurement of optical density at $415 \mathrm{~nm}$ using $\rho$-nitrophenyl- $\beta$-D-glucuronide as a substrate. Data are the mean \pm standard deviations of triplicate measurements. The experiment was repeated three times, and similar results were obtained. Different letters in each horizontal data column indicate significant differences at $P=0.01$ by $t$ test. 
Table 2. Primer pairs used for gene mutagenesis and expression detection in Xanthomonas oryzae pv. oryzicola

\begin{tabular}{|c|c|c|}
\hline Purpose, prime pair & Sequence $\left(5^{\prime} \text { to } 3^{\prime}\right)^{\mathrm{a}}$ & Description \\
\hline \multicolumn{3}{|l|}{ Mutagenesis } \\
\hline hраBIF/ & ATACCCGGGGCACATGACATCCCT/ & \\
\hline hpaBIR & TATGGATCCCGTTGGTGAGACATGCA & A 705-bp left fragment targeting $h p a B$ \\
\hline hpaBIIF/ & ATAGGATCCTACAGGCCTGTTGGCAT/ & \\
\hline hpaBIIR & 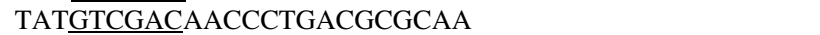 & A 404-bp right fragment targeting $h p a B$ \\
\hline zurIF/ & AAT $\overline{\text { GGATCC }}$ GTGCCGAAGTGCCGCTC/ & \\
\hline zurIR & ATATCTAGACGACGTGGTGATGCGGTG & A 328-bp left fragment targeting zur \\
\hline zurIIF/ & TTATCTAGAGAAGTGCATGGGTTATGC/ & \\
\hline zurIIR & TATGTCGACCCTGGAACGGTGCGTCGAT & A 606-bp right fragment targeting $z u r$ \\
\hline $\operatorname{lrpXIF/}$ & ATA $\overline{\text { GGATCC}} C G G C C T G C A T T G G C A G C /$ & \\
\hline $\operatorname{lrpXIR}$ & TATTCTAGACGCTCAGGCGCGGGCTG & A 621-bp left fragment targeting $\operatorname{lrpX}$ \\
\hline lhrpXIIF/ & AATTCTAGAAGTCCAGATGTGGAAGACC/ & \\
\hline $\operatorname{lrpXIIR~}$ & TAA $\overline{\text { GTCGACTGCGACAGGCCGGTGACC }}$ & A 405-bp right fragment targeting $\operatorname{lrp} X$ \\
\hline colRIF/ & AATGGATCCCCAATACCGACAAGATCAG/ & \\
\hline colRIR & ATATCTAGAAAGCCGTTCGATGTGCCG & A 566-bp left fragment targeting $\mathrm{col} R$ \\
\hline colRIIF/ & AATTCTAGATAATCGCCAAGATTTGC/ & \\
\hline colRIIR & 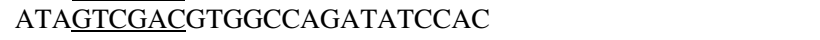 & A 305-bp right fragment targeting colR \\
\hline colsIF/ & AAT $\overline{G G A T C C} C G T A C G G G C G A G T T G /$ & \\
\hline colsIR & ATACTGCAGTGTGCGATCTATA & A 220-bp left fragment targeting $\mathrm{colS}$ \\
\hline colsIIF/ & AATCTGCAGACTGGTTTTCCACG/ & \\
\hline colSIIR & ATTTCATGCGAAGTGGAAGTGC & A 512-bp right fragment targeting $\mathrm{col} S$ \\
\hline $\operatorname{trh\mathrm {IF}/}$ & AATGGATCCTGTACGCGTGGCTGTTCTAT/ & \\
\hline $\operatorname{trh} \mathrm{IR}$ & ATATCTAGACTGCAATCTGTGCGGAGATC & A 630-bp left fragment targeting $t r h$ \\
\hline trhIIF/ & AATTCTAGATCGGCCTGTTTCTCAGC/ & \\
\hline $\operatorname{trh} \mathrm{IIR}$ & ATAGTCGACTCGGTGCCTCTGTCC & A 207-bp right fragment targeting trh \\
\hline phrpD51IF/ & 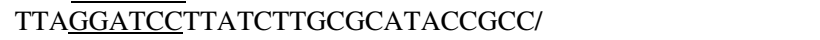 & \\
\hline phrpD51IR & ATATCTAGAAGGTTCCGGTCGATCCTCG & A 534-bp left fragment targeting phrpD51 \\
\hline phrpD51IIF/ & AATTCTAGATTCAATACCAGTTCGCCAGAC/ & \\
\hline phrpD51IIR & ATAGTCGACGCGTGCGGCGCGTGGATCG & A 275 right fragment targeting $p h r p D 51$ \\
\hline phrpD52IF/ & AATGGATCCGTCGCTGGAAGGCCAGGA/ & \\
\hline phrpD52IR & ATATCTAGACCGCCGCGGTGGCCCTGTC & A 428-bp left fragment targeting $p h r p D 52$ \\
\hline phrpD52IIF/ & AATTCTAGACGCCCATGACCATGCAGCTT/ & \\
\hline phrpD52IIR & TATGTCGACCAATCGGCACCAGCATCACC & A 268-bp right fragment targeting $p h r p D 51$ \\
\hline \multicolumn{3}{|l|}{ Western blot constructs } \\
\hline Hpa1F/ & TATGAGCACGCGAAAAAAACTTTTCTCAAC/ & \\
\hline Hpa1-c-MycR & $\begin{array}{l}\text { ATA } \overline{\text { AAGCTTCTACAGATCTTCTTCAGAAATAAGTTTTTGTTCC }} \\
\text { TGCATCGATCCGCTGTC }\end{array}$ & $\begin{array}{l}\text { A 676-bp fragment of hpal with its own promoter } \\
\text { fused with a c-Myc tag }\end{array}$ \\
\hline Нра2F/ & TATGAGCACCAGAGGGGGAAGTGGAAAAT/ & \\
\hline Hpa2-c-MycR & $\begin{array}{l}\text { AA } \text { CTAGCTTCTACAGATCTTCTTCAGAAATAAGTTTTTGTTCTT } \\
\text { CTCAACACACCA }\end{array}$ & $\begin{array}{l}\text { A } 810 \text {-bp fragment of } h p a 2 \text { with its own promoter } \\
\text { fused with a c-Myc tag }\end{array}$ \\
\hline HrpFF/ & GAGCACGTTTAAGTTACCCAACCAAAACCTG/ & \\
\hline HrpF-c-MycR & $\begin{array}{l}\text { TATAAGCTTTTACAGATCTTCTTCAGAAATAAGTTTTTGTTCT } \\
\text { CTGCGACGTATCCTGAC }\end{array}$ & $\begin{array}{l}\text { A 3,106-bp fragment of } h r p F \text { with its own promoter } \\
\text { fused with a c-Myc tag }\end{array}$ \\
\hline \multicolumn{3}{|c|}{ c } \\
\hline phrcCF/ & ATAGAATTCTCGGCCTGGTGGCGCGAG/ & \\
\hline phrcCR & ATTAAGCTTTGACGTTCCCTCTGCTAG & A 285-bp promoter of hrpA operon \\
\hline phpa3F/ & ATAGAATTCAACGCTGACGCTGATGAA/ & \\
\hline phpa3R & ATT $\overline{A A G C T T G A G C G G G C C G C A T A T T G ~}$ & A 291-bp promoter of $h p a 3$ \\
\hline phrpGF/ & ATAGAATTCGCCGGTCTCTCTCTTGGG/ & \\
\hline phrpGR & AATAAGCTTCAGGTGGGCGTCCCGTGG & A 760-bp promoter of $h r p G$ \\
\hline phrpXF/ & ATAAAGCTTGCCGGTCTCTCTCTTGGG/ & \\
\hline phrpXR & AATGAATTCCAGGTGGGCGTCCCGTGG & A 760-bp promoter of $h r p X$ \\
\hline phrpD51F/ & TATGAATTCACCACAGTGCGACGACGAG/ & \\
\hline phrpD51R & ATT $\overline{\text { AAGCTTACTGGTATTGAAGCGAAGCG }}$ & A 370-bp $h r p D$ operon promoter \\
\hline phrpD52F/ & ATAGAATTCGAAAACCTGCAGGCCTTG/ & \\
\hline phrpD52R & ATTAAGCTTGAACCTCCTGAGCCGCCTG & A 209-bp promoter-like region upstream of $h r p D 5$ \\
\hline phrcTlF/ & TATGAATTCTCATACCATTCCCAGG/ & \\
\hline phrcT1R & TAT $\underline{A A G C T T A G C T G A T G C A G C A A C G A C C ~}$ & A 261-bp promoter of $h r p B$ operon \\
\hline phrcT2F/ & 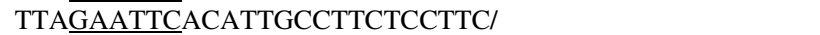 & \\
\hline phrcT2R & ATAAAGCTTTTGAATCTTCTCCACACTG & A 233-bp promoter-like region upstream of $h r c T$ \\
\hline phpalF/ & TAT $\overline{\text { GAATTCGCGAAAAAAACTTTTCTCAA/ }}$ & \\
\hline phpalR & ATTAAGCTTCGTGGCGATTCCTCTCTGATT & A 232-bp promoter of hpal \\
\hline phpa2F/ & TATGAATTCAGAGGGGGAAGTGGAAAAT/ & \\
\hline phpa2R & TATAAGCTTGTTTCGTTACCTCGATCTC & A 216-bp promoter of $h p a 2$ \\
\hline ресрАF/ & ATAGAATTCAGGCGCAGTCGGCAAT/ & \\
\hline pecpAR & TAA $\overline{\text { GGATCC}}$ AGTGACTCTCCGTGT & A 466-bp promoter of Xoryp_01688 \\
\hline hrpD6F1/ & ATAGGATCCATGTTCGATGCAATGAC/ & \\
\hline hrpD6R1 & ATTGGTACCTTACCGCATGCTGGC & A 243-bp ORF of $h r p D 6$ \\
\hline phpa1GUSF/ & TAT $\overline{G G T A C C G C G A A A A A A A C T T T T C T C A A C / ~}$ & \\
\hline phpa1GUSR & 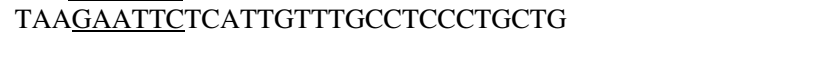 & $\begin{array}{l}\text { A 2,044-bp hpal promoter- } \beta \text {-glucuronidase (GUS) } \\
\text { fusion }\end{array}$ \\
\hline gusF/ & ATAAAGCTTTTACGTCCTGTAGAAACCC/ & \\
\hline gus R & TAAGAATTCTCATTGTTTGCCTCCC & A 1,830-bp gusA gene \\
\hline
\end{tabular}

\footnotetext{
${ }^{a}$ Added restriction sites are underlined.
} 
al. 2006). Interestingly, the GUS activity driven by the $h r p X$ promoter in the $\operatorname{lrp} X$ mutant was significantly higher than that in zur and colR mutants, which was significantly lower than that in $h r p X$, cols, and trh mutant backgrounds and in the wild-type RS105, respectively (Fig. 3C). The GUS activity of the hrpX promoter was lowest in the hrpG mutant compared with the other mutants (Fig. 3C). The above data suggest that not only does Trh positively regulate the expression of $\mathrm{HrpG}$ which, in turn, plays roles in regulation of hrpX and other hrphrc-hpa gene expression but Zur, ColR, ColS, and Trh also have impacts on the expression of HrpX, which subsequently
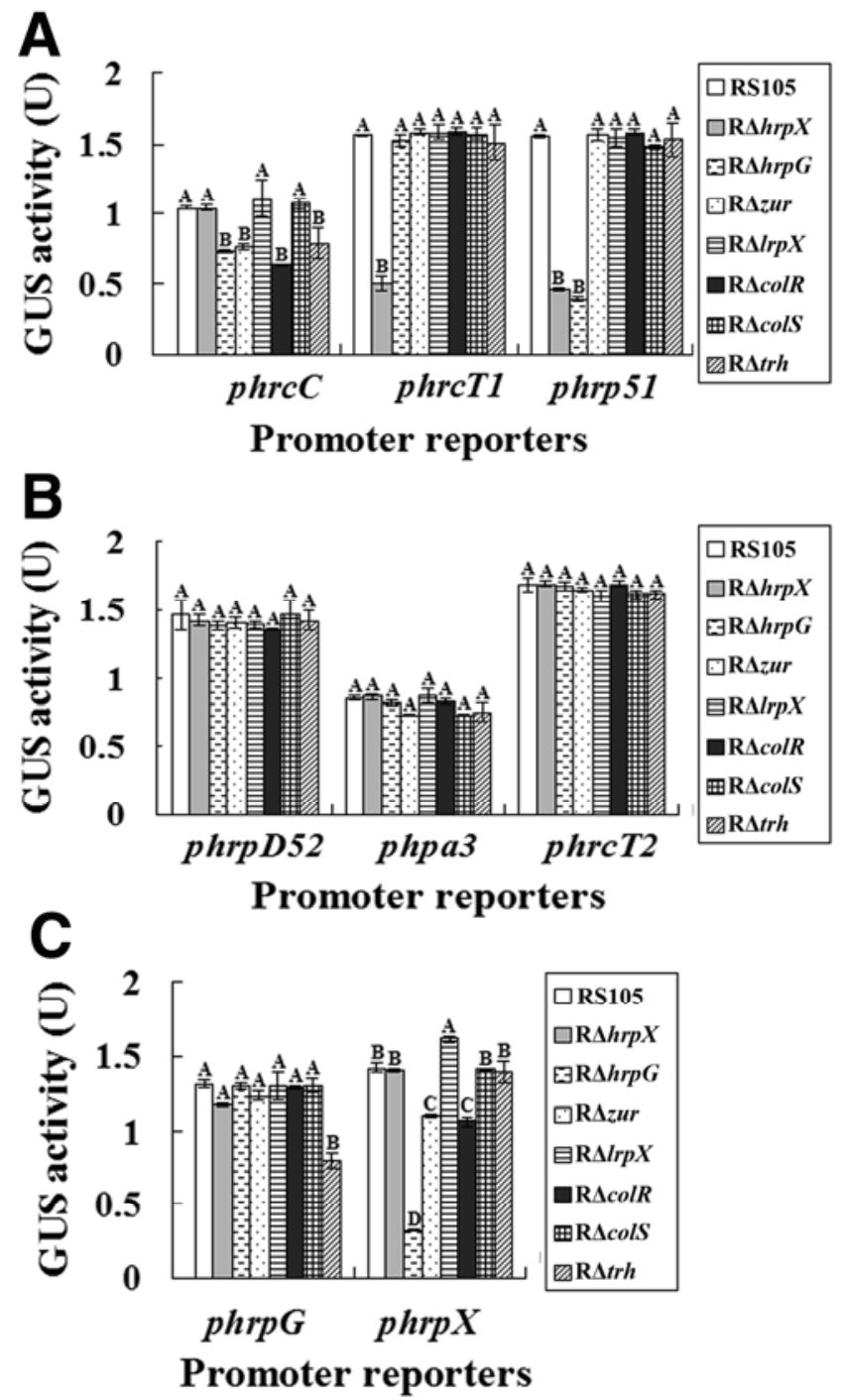

Fig. 3. Regulatory roles of other global regulators (Zur, LrpX, ColR, ColS, and $\operatorname{Trh}$ ) in the expression of hypersensitive response and pathogenicity (hrp)A, hrpB, hrpD, and $h r p$-associated ( $h p a) 3$ operons and $h r p G$ and $h r p X$ genes of Xanthomonas oryzae pv. oryzicola. $\mathbf{A}$ and $\mathbf{B}, \beta$-Glucuronidase (GUS) activities of hrp promoter-gusA reporters, phrcCGUS, phrcT1GUS, phrp51GUS, phrpD52GUS, phpa3GUS, and phrcT2GUS in different genetic backgrounds of the wild-type RS105 and mutants of $h r p G$ (R $\Delta h r p G), h r p X(\mathrm{R} \Delta h r p X), z u r(\mathrm{R} \Delta z u r), \operatorname{lrp} X(\mathrm{R} \Delta l r p X), c o l R(\mathrm{R} \Delta c o l R)$,

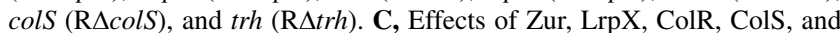
Trh on the expression of $h r p G$ and $h r p X$ genes revealed by GUS activity of $h r p G$ promoter- and $h r p X$ promoter-gusA reporters, respectively, in the deletion mutant backgrounds of $\mathrm{R} \Delta z u r, \mathrm{R} \Delta l r p X, \mathrm{R} \Delta c o l R, \mathrm{R} \Delta \operatorname{col} S$, and $\mathrm{R} \Delta$ trh. X. oryzae pv. oryzicola strains were cultured in XOM3 medium for $16 \mathrm{~h}$ and GUS activities were determined by measurement of optical density at $415 \mathrm{~nm}$ using $\rho$-nitrophenyl- $\beta$-D-glucuronide as a substrate. Data are the mean \pm standard deviations of triplicate measurements. The experiment was repeated twice, and similar results were obtained. controls other hrp-hrc-hpa gene expression. However, the decrease in hrpX-gusA expression in the colR mutant is contradictory to the results observed in $X$. campestris pv. campestris, in which a mutation in colR has no effect on $h r p X$ expression (Zhang et al. 2008).

To assess whether the expression of $h r c C$, $h r p D 5, h r c T$, $h r p E$, and $h p a 3$ was influenced by mutations in $h r p G, h r p X$, $z u r, \operatorname{lrp} X, \operatorname{colR} / S$, and trh genes, we used Northern blot analysis to detect transcript levels of the target genes with RNA isolated from the mutant strains and the wild-type RS105 grown in XOM3 for $16 \mathrm{~h}$. The results showed that $h r p E$ was still expressed in the $h r p X$ mutant $(\mathrm{R} \Delta h r p X)$, albeit at lower levels than in the wild-type strain (Fig. 4), but $h r p E$ was strongly induced in the $\operatorname{lrp} X$ mutant (R $\Delta \operatorname{lrpX})$. Compared with the wild-

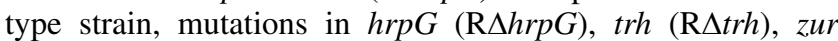
(RAzur), and colR (RAcolR) had little effect on hrpE expression (Fig. 4). The Northern blot results also revealed that the mutation in either $h r p G$ or $h r p X$ did not completely abolish transcription of $h r p E$, implying that other factors may be involved in regulation of $h r p E$ expression. Furthermore, no hybridization signals were detected for $h r c C, h r c T, h r p D 5$, and $h p a 3$ transcripts and, therefore, we were unable to determine the effects of the mutations on these targets. This could be due to expression levels of $h r c C, h r c T, h r p D 5$, and $h p a 3$ that may be suboptimal for detection by Northern blot.

\section{The $h r p D$ operon contains eight genes from $h r c Q$ to $h r p E$ in $X$. oryzae pv. oryzicola.}

We examined the sequence between the hrpA and hrpD5 genes of $X$. oryzae pv. oryzicola. Within the ribosomal binding site (RBS) for $h r p E$, the RBS sequence has been changed from GGA in X. campestris pv. vesicatoria (Weber et al. 2007) to GCC in X. oryzae pv. oryzicola and X. oryzae pv. oryzae (data not shown). In $X$. oryzae pv. oryzicola, the putative PIP-box promoter sequence overlaps with the start codon of the hrpD5 gene, as is the case in X. campestris pv. vesicatoria (Weber et al. 2007). This indicates that the hrpE gene belongs to the $h r p D$ operon in $X$. oryzae pv. oryzicola, as seen in $X$. oryzae pv. oryzae (Cho et al. 2008).

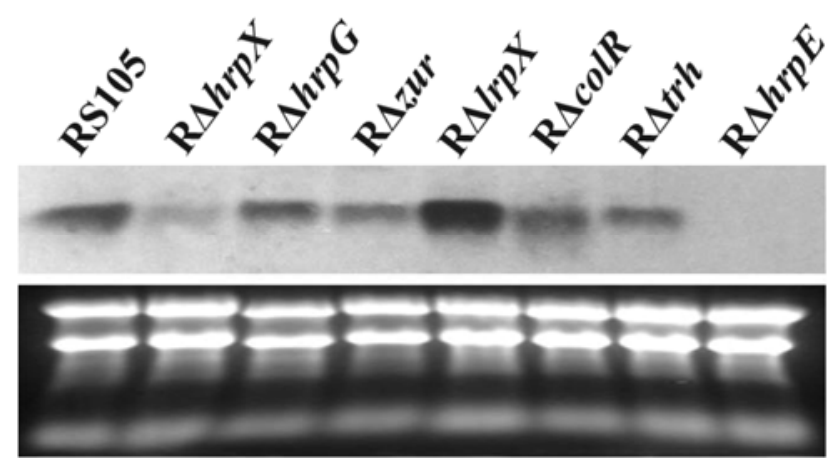

Fig. 4. Expression profiles of the hypersensitive response and pathogenicity $(h r p) E$ gene in the mutant strains of other global regulatory factors Zur, LrpX, ColR, and Trh compared with the mutants of the key regulators HrpG and HrpX of Xanthomonas oryzae pv. oryzicola. RS105 (wild-type), $\mathrm{R} \Delta h r p X$ (hrpX mutant), R $\Delta h r p G$ (hrpG mutant), R $\Delta z u r$ (zur mutant), $\mathrm{R} \Delta \operatorname{lrpX}$ (lrpX mutant), R $\Delta$ colR (colR mutant), R $\Delta \operatorname{col} S$ (colS mutant), $\mathrm{R} \Delta t r h$ (trh mutant), and $\mathrm{R} \Delta h r p E$ ( $h r p E$ mutant, used for negative control) were incubated in $h r p$-inducing medium XOM 3 for $16 \mathrm{~h}$ and then the total RNAs were extracted after incubation. Northern hybridization was performed to analyze transcript levels of $h r p E$ in $X$. oryzae pv. oryzicola strains. Approximately $30 \mu \mathrm{g}$ of the total RNAs of each sample were loaded onto each lane and the blot was probed with Biotin-labeled $h r p E$, which was polymerase chain reaction-amplified. Total RNAs were electrophoretically separated on $1.2 \%$ agarose gel and stained with ethidium bromide to detect the quality of the extracted RNAs (bottom). The experiment was repeated twice with similar results. 
To determine the transcript unit between $h p a P$ and $h r p E 3$, we first generated deletions in the phrpD51 and phrpD52 promoters, R $\Delta h r p D 51$ and R $\Delta h r p D 52$ (Table 1; Fig. 5A), respectively. The wild-type and mutant strains were incubated in XOM3 for $16 \mathrm{~h}$, and then RT-PCR was performed to assess the expression of individual genes from $h r c Q$ to $h r p E 3$ in the $\mathrm{R} \Delta h r p G, \mathrm{R} \Delta h r p X, \mathrm{R} \Delta h r p D 51$, and $\mathrm{R} \Delta h r p D 52$ mutants compared with the expression of those in the wild-type RS105. The results demonstrated that the expression of $h r c R, h r c S$, $h r c Q, h p a A$, and $h r p D 6$ genes is controlled by the $h r p D$ operon promoter phrpD51, as was seen in the $h r p G$ and $h r p X$ mutants. Particularly, hrpD5 expression was unaffected when the promoters phrpD51 and phrpD52 and the hrpG and hrpX genes were mutated (Fig. 5A), implying that the hrpD5 expression is $h r p G$ and $h r p X$ independent and controlled by other unknown regulatory factors. The RT-PCR results also showed that a mutation in the hrpD52 promoter completely abolished $h p a A$ expression (Fig. 5A). More importantly, the $h r p E$ and $h p a B$ genes were not expressed in the phrpD51 promoter mutant, R $\Delta h r p D 51$ (Fig. 5A), which suggests that they are members of the $h r p D$ operon. Previously, we believed they were part of the hrpE operon based on homology analysis of the core hrp cluster sequence (Zou et al. 2006).

To confirm the above results, we also used RT-PCR to determine the transcriptional linkage in different regions of the $h r p$ gene cluster from hpaP through hrpE3 in RS105. Primer pairs in Supplementary Table 3 were used to detect the intergenic junction between these hrp genes, and the results indicated that the $h r p D$ operon is transcribed as a single polycistronic mRNA extending from $h r c Q$ to $h p a B$ (Fig. 5B). PCR products spanning hrcQ-hrcR, hrcR-hrcS, hrcS-hpaA, hpaA-hrpD5, hrpD5-hrpD6, hrpD6-hrpE, hrpE-hpaB, and hrcS-hpaB were obtained, suggesting that they are transcribed as one transcriptional unit. These results also proved that, although phrpD52 shows promoter activity in the GUS assay, it is not the promoter of the hrpD5 gene. Furthermore, this information helps identify the members of the $h r p D$ operon in $X$. oryzae pv. oryzicola. These results are consistent with observations in $X$. oryzae pv. oryzae (Cho et al. 2008) but different from those in $X$. campestris pv. vesicatoria, where hrpD6 is one of the genes in the $h r p E$ operon (Weber et al. 2007).

\section{HrpD6 controls the expression} of hpa1, hpa2, hrcC, $h r c T$, and $h p a B$.

Our previous work showed that, $48 \mathrm{~h}$ after infiltration with a bacterial suspension of $1 \times 10^{8} \mathrm{CFU} / \mathrm{ml}$, the hrpD6 mutant $\mathrm{R} \Delta h r p D 6$ is unable to elicit HR in nonhost tobacco (cultivar Xanthi) or cause water-soaking symptoms in susceptible rice (IR24) (Guo et al. 2010). Moreover, HR induction in tobacco and pathogenicity in rice could be restored in the hrpD6 mutant upon complementation with a construct expressing the $h r p D 6$ gene driven by the $h r p D$ operon promoter (Fig. 2 , phrpD51) (Guo et al. 2010). To evaluate the role of the $X$. oryzae pv. oryzicola HrpD6 in HR induction in tobacco and
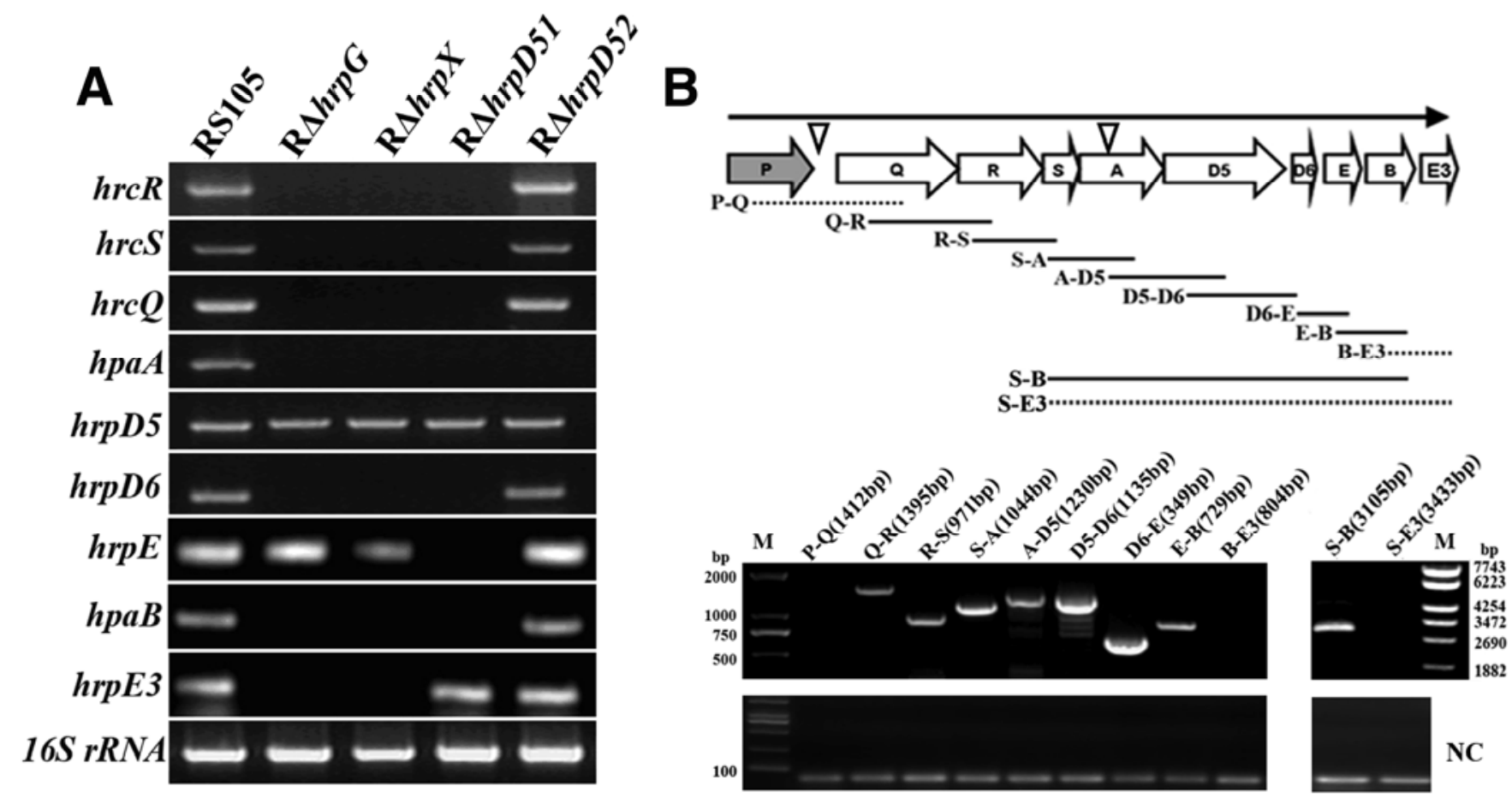

Fig. 5. Reverse-transcription polymerase chain reaction (RT-PCR) analysis of the transcriptional units of hypersensitive response and pathogenicity ( $h r p$ )associated (hpa)P to $h r p E 3$ genes in Xanthomonas oryzae pv. oryzicola. A, Transcriptional detection of $h r p$-conserved $(h r c) Q$ to $h r p E 3$ genes revealed by RT-PCR with specific primers in the deletion mutants of $h r p G$ and $h r p X$ genes (R $\Delta h r p G$ and $\mathrm{R} \Delta h r p X)$, phrpD51 and phrpD52 promoter deletion mutants (R $\Delta$ rpD51 and R $\Delta h r p D 52$ ), and the wild-type $X$. oryzae pv. oryzicola RS105 after incubation in the hrp-inducing medium XOM3 for $16 \mathrm{~h}$. The phrpD51 and phrpD52 promoter regions are shown to the right of this figure marked as delta. The $16 S$ rRNA gene was used as the standard control. B, Schematic representation of the $h r p D$ operon and RT-PCR products amplified using primers designed to span the intergenic junctions. The black arrow indicates the extension and transcription direction of the $h r p D$ operon, and the operon arrows represent the open reading frames of $h r p$ genes: $h r c Q(\mathrm{Q}), h r c R(\mathrm{R}), h r c S(\mathrm{~S})$, $h p a A$ (A), $h r p D 5$ (D5), $h r p D 6$ (D6), $h r p E$ (E), $h p a B$ (B), and $h r p E 3$ (E3) after the $h p a P(\mathrm{P})$ gene of the $h r p C$ operon. The thick black lines indicate the 11 PCR products and the expected sizes of the corresponding RT-PCR products after the strain was incubated in XOM3 for $16 \mathrm{~h}$. P-Q denotes PCR reactions with primer pairs $14 \mathrm{~F}-15 \mathrm{Q}, \mathrm{Q}-\mathrm{R}$ is $15 \mathrm{~F}-16 \mathrm{R}, \mathrm{R}-\mathrm{S}$ is $16 \mathrm{~F}-17 \mathrm{R}$, S-A is $17 \mathrm{~F}-18 \mathrm{R}, \mathrm{A}-\mathrm{D} 5$ is $18 \mathrm{~F}-19 \mathrm{R}, \mathrm{D} 5-\mathrm{D} 6$ is $19 \mathrm{~F}-20 \mathrm{R}, \mathrm{D} 6-\mathrm{E}$ is $20 \mathrm{~F}-21 \mathrm{R}, \mathrm{E}-\mathrm{B}$ is $21 \mathrm{~F}-22 \mathrm{R}$, B-E3 is 22F-23R, S-B is $17 \mathrm{~F}-22 \mathrm{R}$, and S-E3 is 17F-23R. The latter two were used to confirm whether the hrcS and hrpE3 genes are intergenic. The lower panel shows the agarose gel analysis of the RT-PCR products. In addition, the extracted RNAs were used directly as the templates for PCR to ensure samples were free of DNA contamination as the negative control (NC) where only primer dimers formed. M, DL 2000 DAN ladder (left) and $\lambda$-EcoT14 DNA ladder (right) (TaKaRa). All the experiments were repeated three times and similar data were obtained. 
pathogenicity in rice, we investigated the expression of all the hrp-hrc-hpa genes in the hrpD6 mutant R $\Delta h r p D 6$ using RTPCR, following interaction with rice suspension cells for $16 \mathrm{~h}$. The result showed that, in the hrpD6 mutant, hpa2, hpal, and $h p a B$ transcripts were undetectable, and the expression levels of $h r c C$ and $h r c T$ were reduced (Fig. 1B). Meanwhile, the expression of hpa2, hpal, hpaB, $h r c C$, and $h r c T$ was restored to the wild type in the complementation strain CR $\Delta h r p D 6$, which harbors a plasmid carrying the hrpD6 gene controlled by the $h r p D$ operon promoter (Fig. 1B). On the other hand, the expression of other $h r p-h r c-h p a$ genes, including $h r p G$ and $h r p X$ in either R $\Delta h r p D 6$ or CR $\Delta h r p D 6$, was similar to that in the wild-type RS105 (Fig. 1B). Additionally, the expression of hpa2, hpal, $h p a B, h r c C$, and $h r c T$ in the $h r p D 6$ overexpression strain, RS105(hrpD6), was higher than that in the wild-type RS105 (Fig. 1C). These results strongly suggest that HrpD6 upregulates the expression of hpa2, hpal, hrcC, $h r c T$, and hpaB and that hrpD6 expression is positively regulated by HrpX.

In order to confirm whether HrpD6 is involved in the regulation of hpa2, hpal, $h r c C, h r c T$, and $h p a B$, constructs were generated in which their promoters were fused with gusA to yield phpa1GUS, phpa2GUS, phrcCGUS, phrcT1GUS, and phrpD51GUS (Table 1). These constructs were then introduced into the hrpD6 mutant (R $\Delta h r p D 6$ ) and the wild-type RS105. The GUS activity of the resulting reporter stains was measured after $16 \mathrm{~h}$ of growth in the $h r p$-inducing medium XOM3. With the exception of phrpD51GUS, the results showed that the GUS activity of each reporter plasmid was significantly lower than that in the wild type (Fig. 6A), indicating that HrpD6 regulates the expression of $h p a 2, h p a l$, and $h p a B$ and partially controls the transcript levels of $h r c C$ and $h r c T$. We also investigated whether HrpD6 has some regulatory effect on hrpG and $h r p X$ expression by introducing constructs with $h r p G$ and $h r p X$ promoters fused to gusA (phrpGGUS and phrpXGUS) into R $\triangle h r p D 6$ and the wild-type RS105. The GUS activity of these two reporter plasmids in the hrpD6 mutant background was similar to that in the wild type (Fig. 6A), suggesting that HrpD6 has no obvious influence on $h r p G$ or $h r p X$ expression in X. oryzae pv. oryzicola.

The PIP-box in the hrp promoter regions is normally the ciselement where HrpX binds in Xanthomonas spp. (Furutani et al. 2006; Koebnik et al. 2006; Wengelnik and Bonas 1996; Wengelnik et al. 1996). The presence of a perfect PIP-box in the hpal promoter region, analyzed elsewhere in this work, suggests that the expression of hpal is positively regulated by HrpX as detected at the transcriptional level in our previous (Zou et al. 2006) and present (Fig. 1B) reports. However, the hpal transcript was undetectable in the hrpD6 mutant (Fig. $1 \mathrm{~B})$, which led us to assume that hpal expression is not regulated by HrpX but by HrpD6. For this, a constitutive promoter that lacks a PIP-box from Xoryp_01688 was used here. Xoryp_01688 encodes an extracellular protease whose transcription is not regulated by HrpX (unpublished data). To sup-
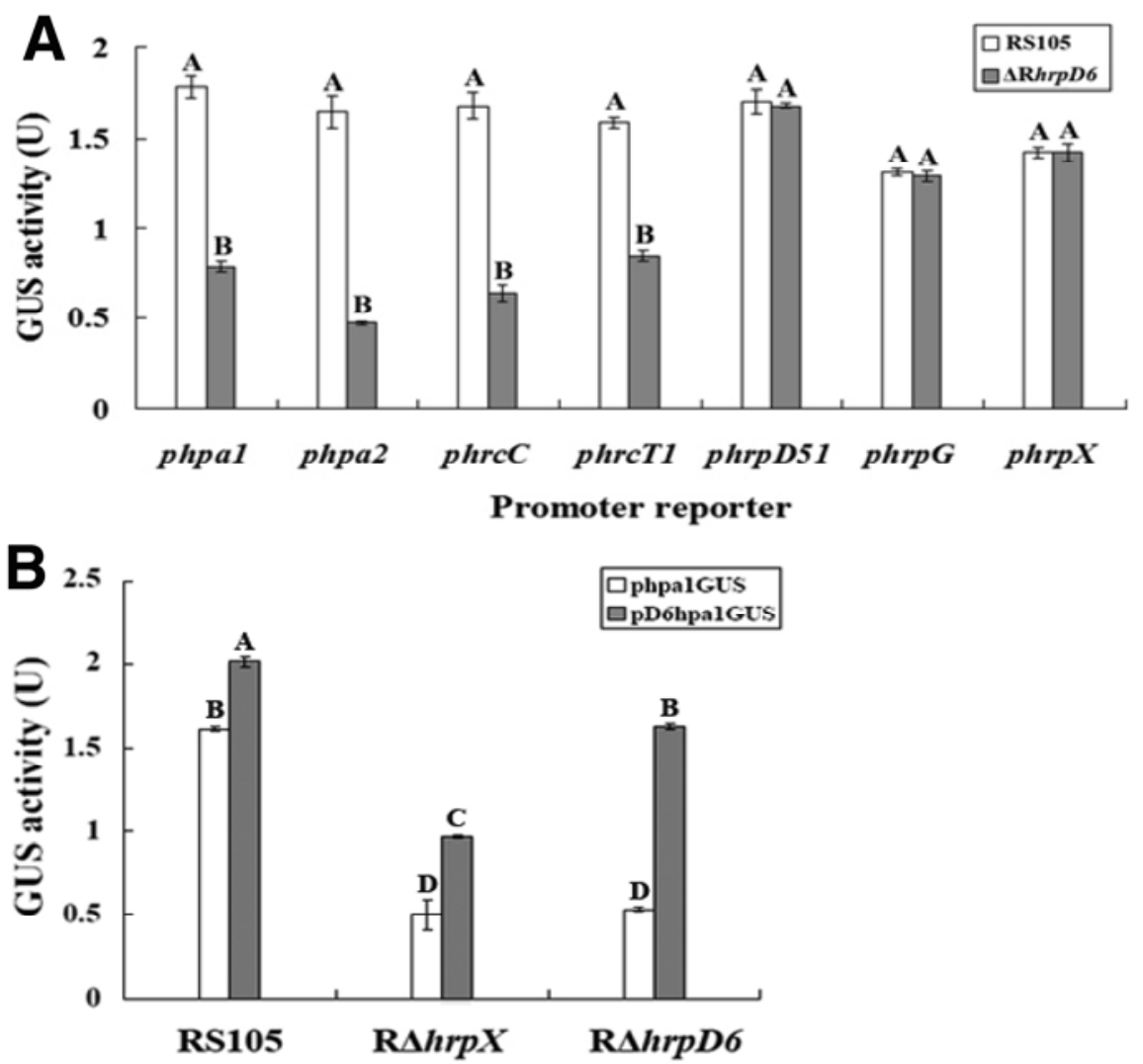

Fig. 6. Regulation of HrpD6 on expression of hypersensitive response and pathogenicity ( $h r p$ )-associated (hpa) $1, h p a 2, h r p$-conserved ( $h r c) C$, $h r c T, h p a B$, hrpG, and hrpX in Xanthomonas oryzae pv. oryzicola. A, Comparison of $\beta$-glucuronidase (GUS) activities in the wild-type RS105 and the hrpD6 mutant $R \Delta h r p D 6$ backgrounds driven by $h p a l, h p a 2, h r c C$, hrcT, hrpE, hpaB, $h r p G$, and $h r p X$ promoter-GUS reporters phpa1GUS, phpa2GUS, phrcCGUS, phrcT1GUS, phrpD51GUS, phrpGGUS, and phrpXGUS, respectively. B, HrpX-independent expression of hpal regulated by HrpD6. A constitutive promoter of Xoryp_01688 that lacks a plant-inducible promoter-box was fused with the hrpD6 open reading frame in the vector phpa1GUS which is the hpal promoter-GUS reporter, giving pD6hpa1GUS. The GUS activities of pD6hpa1GUS and phpa1GUS in the wild-type RS105, the $h r p X$ mutant R $\Delta h r p X$, and the $h r p D 6$ mutant were investigated. All the reporter strains above were cultured in XOM3 medium for $16 \mathrm{~h}$ and GUS activities were then determined by measurement of optical density at $415 \mathrm{~nm}$ using $\rho$-nitrophenyl- $\beta$-D-glucuronide as a substrate. Data are the mean \pm standard deviations of triplicate measurements. Different letters in each horizontal data column indicate significant differences at $P=0.01$ by $t$ test. The experiment was repeated twice and yielded similar results. 
port the above hypothesis, we used the Xoryp_01688 promoter to drive the expression of $h r p D 6$ with $h p a l:: g u s A$ as a reporter (pD6hpa1GUS) (Table 1) in the $h r p X$ mutant $\mathrm{R} \Delta h r p X$, the hrpD6 mutant R $\Delta$ hrpD6, and the wild-type RS105, respectively. For comparison, the hpal::gusA reporter (phpa1GUS) (Table 1) was used as a control. Indeed, the GUS activity of pD6hpa1GUS was significantly $(P=0.01, t$ test $)$ higher than that of phpa1GUS in either the wild-type strain RS105, the $h r p X$ mutant $\mathrm{R} \Delta h r p X$, or the hrpD6 mutant R $\Delta h r p D 6$ (Fig. $6 \mathrm{~B})$, demonstrating that HrpD6 regulates the expression of hpal. The GUS activity of pD6hpa1GUS in the hrpD6 mutant R $\Delta h r p D 6$ was almost the same as that of phpalGUS in the wild-type RS105 but was significantly lower than that in either the wild-type RS105 or the $h r p X$ mutant R $\Delta h r p X$ (Fig. 6B), implying that HrpD6 controls hpal expression in an HrpXindependent manner.

\section{HrpD6 controls the secretion}

of the HpaB-dependent TAL effector AvrXa27 but not HrpF.

The loss of expression of hpa2 and hpal in hrpD6 mutant background suggests that this mutation may also effect Hpal and Hpa 2 secretion. To assess this, we used $X$. oryzae pv. oryzicola RS105, an hrpD6 deletion mutant (R $\Delta$ hrpD6), an $h r c V$ T3SS deletion mutant (R $\Delta h r c V)$ deficient in secretion of T3SS effectors, and a deletion mutant lacking hpaB (R $\Delta h p a B)$ in which $\mathrm{HpaB}$ works as an exit control protein in T3SSdependent protein secretion in $X$. campestris pv. vesicatoria (Büttner et al. 2004). For the in vitro analysis of the T3SS effectors Hpa2 and Hpa1, strains RS105, R $\Delta h r p D 6, \mathrm{R} \Delta h p a B$, and $\mathrm{R} \Delta h r \mathrm{~V}$ were incubated in secretion medium XOM3. Total cell extracts (TE) and culture supernatants (SN) were analyzed by immunoblotting. All proteins tested were secreted by the wild-type strain but were not detectable in the SN of the $h r c V$ deletion mutant (Fig. 7), indicating that secretion of these proteins is through the T3SS of X. oryzae pv. oryzicola. Because the mutation in $h r p D 6$ attenuated $h p a B$ expression (Fig. 1B), we tested the secretion of Hpa2, Hpa1, AvrXa27, and HrpF in both the $h p a B$ nonpolar mutant $\mathrm{R} \triangle h p a B$ and the hrpD6 deletion mutant RAhrpD6. The result showed that Hpa2 and Hpa1 were not detected in TE and SN of the hrpD6 mutant (Fig. 7C and D) but $\mathrm{Hpa} 2$ and AvrXa27 were undetectable only in the $\mathrm{SN}$ of $h p a B$ and $h r p D 6$ deletion mutants (Fig. 7A and D). The data also showed that Hpal was only secreted in SN of the $h p a B$ deletion mutant (Fig. 7B), and that HrpF secretion was observed in both $h p a B$ and hrpD6 deletion mutants (Fig. 7B). This suggests that the mutation in hrpD6 inhibits transcription of hpa 2 and hpal (Fig. 1B) and, hence, Hpa2 and Hpa1 proteins are not detected in the SN. However, HrpD6 acts upstream in the $\mathrm{HpaB}$ regulatory cascade (Fig. 1B) and, therefore, HpaBdependent T3SS effectors AvrXa27 and Hpa2 are not secreted in SN of hrpD6 and hpaB mutants, whereas the secretion of the HpaB-independent translocator, HrpF, is not affected by the hrpD6 mutation.

\section{DISCUSSION}

In this study, we investigated the role of $h r p G$ and $h r p X$ in the regulation of the hrp-hrc-hpa gene cluster of $X$. oryzae pv. oryzicola and identified a novel regulator, HrpD6, within this hrp$h r c-h p a$ cluster. The expression of most of the hrp-hrc-hpa genes, excluding $h p a 2, h r c C, h r c T, h r p D 5, h r p E$, and $h p a 3$, is regulated by both $\mathrm{HrpG}$ and $\mathrm{HrpX}$. This follows the general principle that HrpG regulates the expression of the $h r p A$ operon and $h r p X$; and HrpX, in turn, regulates the expression of the $h r p B$ to $h r p F$ operons, in which PIP-box promoters are presumably activated by HrpX (Furutani et al. 2006; Koebnik et al. 2006) in diverse Xanthomonas spp. (Arlat et al. 1991; Furutani et al. 2006; Kamdar et al. 1993; Koebnik et al. 2006; Oku et al. 1995; Wengelnik and Bonas 1996; Wengelnik et al. 1996a and b; Zou et al. 2006). However, in $X$. oryzae pv. oryzicola, transcription of the $h r c C, h r p D 5, h r p E$, and hpa3 genes is still observed when the $h r p G$ and $h r p X$ genes were mutated (Figs. 1, 2,
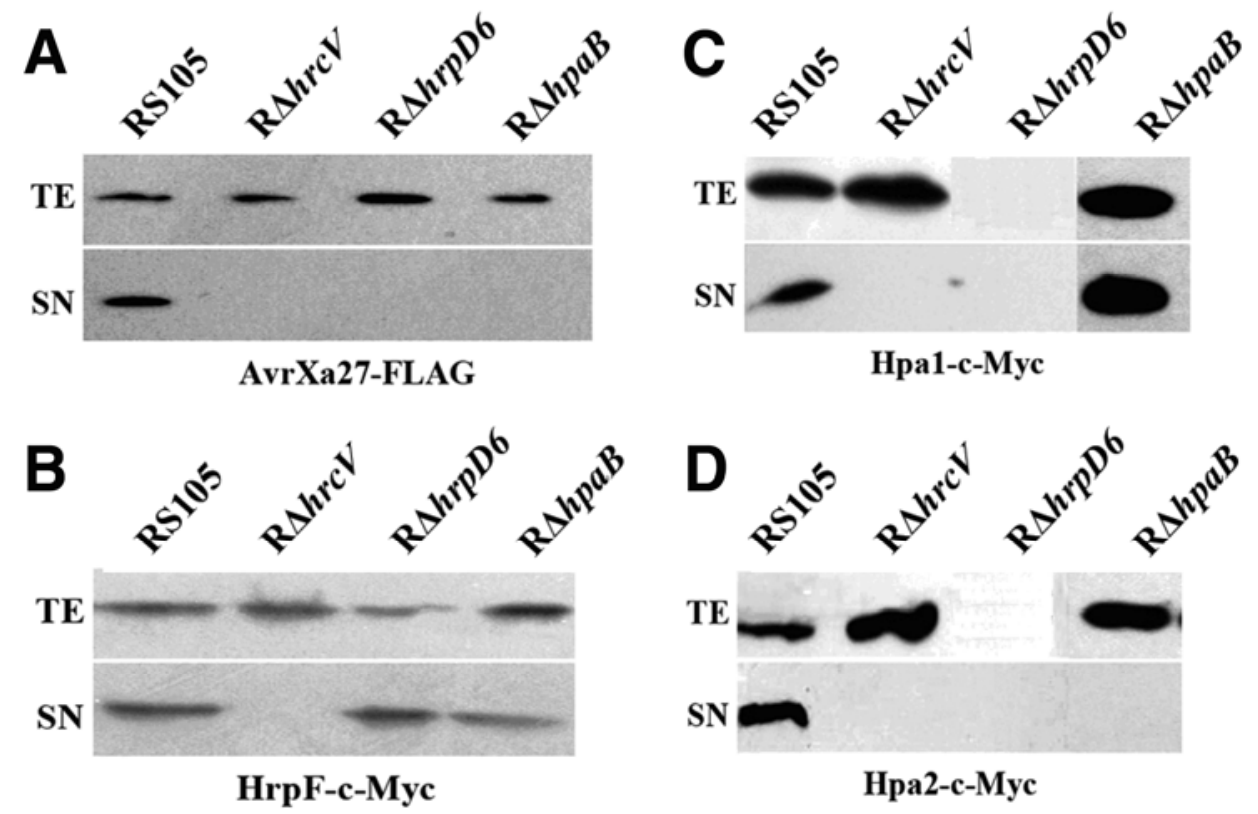

Fig. 7. Influence of hypersensitive response and pathogenicity (Hrp)D6 on secretion of type III secretion system (T3SS) effectors AvrXa27, hrp-associated (Hpa)1, and Hpa2, and T3SS translocator HrpF in Xanthomonas oryzae pv. oryzicola. The hrpD6 mutant R $\Delta h r p D 6$, the hrp-conserved (hrc)V mutant $\mathrm{R} \Delta h r c V$, the $h p a B$ mutant R $\Delta h p a B$, and the wild-type RS105, harboring pAvrXa27-FLAG, pHrpF-c-Myc, pHpa1-c-Myc, or pHpa2-c-Myc, respectively, were induced in the $h r p$-inducing XOM3 medium for $16 \mathrm{~h}$. Bacterial total cell extracts (TE) and culture supernatants (SN) were analyzed by sodium dodecyl sulfate polyacrylamide gel electrophoresis and immunoblotting. A, In vitro secretion of the TAL effector AvrXa27 was analyzed using a monoclonal antiFLAG antibody. B, In vitro secretion of the T3S translocon HrpF protein was detected by using a monoclonal anti-c-Myc antibody. C, In vitro secretion of a harpin protein Hpa1 was immunoblotted with a monoclonal anti-c-Myc antibody. D, In vitro secretion of a lytic transglycosylase Hpa2 was assayed by using a monoclonal anti-c-Myc antibody. This experiment was repeated three times. Results from one representative experiment are shown. 
and 4), indicating that other unknown regulators control their expression. We do not know whether these novel regulatory features exist in other Xanthomonas spp. For instance, $h r c C$ is the only member in the $h r p A$ operon that is highly conserved in many gram-negative animal- and plant-pathogenic bacteria and works as an outer membrane protein of T3SS for secretion of T3SS effectors (Alfano and Collmer 1997; Büttner and Bonas 2002; Büttner et al. 2006; Deng and Huang 1999; Kim et al. 1997; Rossier et al. 2000). In X. campestris pv. vesicatoria, the hrpA operon is activated by HrpG but not by HrpX (Wengelnik and Bonas 1996). In this report, we found that HrpG does not completely abolish the expression of $h r c C$ (Fig. 1B), indicating that other unknown factors may work together with HrpG to regulate expression of $h r c C$ in $X$. oryzae pv. oryzicola. In $X$. campestris pv. campestris, the expression of $h r c C$ is regulated by both HrpG and HrpX (Huang et al. 2009). The novel expression profiles of $h r p$ - $h r c-h p a$ genes regulated by HrpG and HrpX support the hypothesis that there may be pathovar-specific differences in hrp gene expression in Xanthomonas spp.

In $X$. campestris pv. vesicatoria, hrpD5 ( $h r c D)$, hrpD6, and $h r p E$ belong to the $h r p E$ operon. The $h r p E$ promoter lies within the hpaA coding sequence and harbors a thus-far-notconsidered PIP-box that is conserved in all Xanthomonas strains (Weber et al. 2007). However, the transcriptional unit of the $h r c Q$ to $h p a B$ region in $X$. oryzae pv. oryzicola is not consistent with that of $X$. campestris pv. vesicatoria, because there was no expression of the $h r c Q$ to $h r p D 6$ genes, except $h r p D 5$, when the $h r p D$ operon promoter was deleted. Furthermore, expression of the genes from $h r c Q$ to $h r p D 6$ was not impaired by the deletion of the PIP-box promoter within $h p a A$ (Fig. 5), suggesting that the eight genes from $h r c Q$ to $h p a B$ are transcribed as one unit, with the exception of hrpD5. This is consistent with that in $X$. oryzae pv. oryzae (Cho et al. 2008). However, at this time, we do not know why transcription of $h r p D 5$ and $h r p E$ genes is still observed when $h r p G, h r p X$, and the PIP-box promoter of the $h r p D$ operon are mutated. In $X$. oryzae pv. oryzicola as in $X$. campestris pv. vesicatoria, the sequences between hpaA and hrpD5 share 4 bp for the start codon of $h r p D 5$ (ATG) and the stop codon of $h p a A$ (TGA). Furthermore, the sequences spanning hpaA-hrpD5 has an exact match of 46 bp (5'-AACAGGCGGCTCAGGAGGTTCG CCCATGACCATGCAGCTTCGCGTA-3'), including the PIP box (underlined sequences) newly reported in $X$. campestris pv. vesicatoria (Weber et al. 2007). Interestingly, the intergenic primers between the contiguous genes among $h p a A$, hrpD5, hrpD6, hrpE, hpaB, and hrpE3 could detect the expression of $h p a A$ to $h p a B$ by RT-PCR amplification (Fig. 5), indicating that these junctions are expressed as mRNAs. The discrepancy between $X$. oryzae pv. oryzicola and X. campestris pv. vesicatoria with regard to $h p a A$ to $h p a B$ transcription might be a simple difference as species but the mechanisms of the expression of $h r p D 5$ and $h r p E$ in $h r p G$ - and $h r p X$ independent profiles remains a mystery.

In $X$. campestris pv. vesicatoria, HrpD5 is named as $\mathrm{HrcD}$, which is encoded by the first ORF in the $h r p E$ operon (Weber et al. 2007). HrcD is a biotic membrane protein that exhibits weak homology to members of the YscD family, to which HrpW from Ralstonia solanacearum and PrgH from Salmonella typhimurium belong (Pallen et al. 2005). PrgH is an essential component of T3SS needle complex associated with T3SS and has been copurified with the needle subunit PrgI (Kubori et al. 1998). In comparison, in the genus Xanthomonas, HrpE is the major subunit of the Hrp pilus which possesses a two-domain structure with a surface-exposed, positively selected $\mathrm{N}$ terminus and a $\mathrm{C}$ terminal polymerization domain (Weber and Koebnik 2005; Weber et al. 2005). In X. oryzae pv. oryzicola, a mutation in the $h r p E$ gene leads to lack of Hrp pili formation in rice paren- chyma and the inability to attach to rice callus during host cell interactions (Wang et al. 2009). As for Hpa3, little is known about its role in the T3SS. There are two homologs of hpa3 in $X$. campestris pv. vesicatoria (hpaI and hpaD) that are regulated by HrpG and HrpX (Büttner et al. 2007). A mutation in hpa3 has no apparent effect on pathogenicity of X. oryzae pv. oryzae (Cho et al. 2008) or of $X$. oryzae pv. oryzicola but transcription of hpa3 was HrpG and HrpX independent, as are hrcC, hrpD5, and hrpE (Fig. 1B). It has been suggested that $\mathrm{Hpa} 3$ may be a chaperone for secretion of Hpa4 by the T3SS, because it is a small acidic and leucine-rich protein (Sugio et al. 2005). Intriguingly, hpa3 expression was almost completely inhibited in the mutants of $h r p B 1, h r p B 2, h r p B 4$, and hrpB5 in X. oryzae pv. oryzicola (unpublished data), indicating that Hpa3 may play important roles in formation of the T3SS or the Hrp pilus. Considering the results above, we postulate that the $\mathrm{HrcC}$ outer-membrane protein, the extracellular Hrp pilus composed of HrpD5 and HrpE, and the Hpa3 chaperone may be essential for pathogen survival and are expressed independently of HrpG and HrpX in either nutrient-rich medium (NB), $h r p$-inducing medium XOM3, or in planta.

Another interesting finding is that hpa 2 expression was positively regulated by HrpG and HrpD6 but not by HrpX. In addition, $h r c T$ transcription was positively controlled by HrpX but negatively controlled by $\mathrm{HrpG}$ and partially regulated by HrpD6 (Fig. 1B). Our experimental evidence also showed that hpal and hpaB expression seemed to be positively regulated by both HrpG and HrpX (Fig.1B) but, actually, this is not the case. Expression of hpa2, hpal, and $h p a B$ genes was undetectable, and expression levels of the $h r c C$ and $h r c T$ genes were reduced when hrpD6 was mutated in X. oryzae pv. oryzicola RS105 (Figs. 1B, 5, and 6). These data strongly suggest that HrpD6, whose transcription is positively controlled by HrpG and HrpX, positively regulates the expression of hpa2, hpal, and $h p a B$ and upregulates the transcription of $h r c C$ and $h r c T$. Our hypothesis is confirmed by the following aspects. i) HrpD6 has no homologs among genes encoding the T3SS of other gram-negative plant and animal pathogenic bacteria except in Xanthomonas spp. (Weber et al. 2007), implying that HrpD6 is not involved in T3SS formation. ii) HrpD6 controls the hpal expression in an HrpX-independent manner. This was confirmed by using the constitutive promoter of the extracellular protease gene Xoryp_01688 to drive hrpD6 expression which, in turn, regulates the perfect PIP-box promoter of hpal, all of which was monitored by measuring gusA expression in the wild-type RS105, the $h r p X$ deletion mutant $R \Delta h r p X$, and the hrpD6 deletion mutant R $\Delta h r p D 6$ (Fig. 6B). This is consistent with previous reports which found that, just because the HrpX-regulon candidates have promoters containing a perfect or imperfect PIP-box does not necessarily mean they are true HrpX regulons (Furutani et al. 2006, 2009). iii) The HpaBdependent T3SS effectors, like AvrXa27 (Gu et al. 2005) and AvrBs3 (Büttner et al. 2004, 2006), are not detectable in the hrpD6 and $h p a B$ mutants (Fig. 7). These results are consistent with previous studies which showed that $h p a B$ or hrpD6 mutations result in lack of TAL effector secretion. iv) The HpaBindependent T3SS translocator HrpF (Büttner et al. 2004) is detectable in both $h p a B$ and $h r p D 6$ mutants (Fig. 7B), demonstrating that HrpD6 has no effect on the secretion of HpaBindependent T3SS effectors. v) Inhibition of hpa2 and hpal expression and downregulation of $h r c C$ and $h r c T$ in the $h r p D 6$ mutant (Figs. 1B and 6) led to a deficiency in Hpa2 and Hpa1 secretion (Fig. 7) and, possibly, a complete lack of T3SS secretion (not assessed in this report). This indicates that the expression of hpa2, hpal, and hpaB is HrpG- and HrpX-independently regulated by HrpD6 and the expression of $h r c C$ and hrcT genes is co-regulated by HrpG, HrpX, and HrpD6. 
Integrating accumulated knowledge and current expression profiles of the hrp-hrc-hpa genes in Xanthomonas spp., we propose a new working model for regulation of the $X$. oryzae pv. oryzicola hrp system (Fig. 8). Trh, a member of the GntR regulator family (Tsuge et al. 2006), represses the expression of HrpG (Fig. 2B), indirectly resulting in lower expression of HrpX which, in turn, directly regulates the expression of most of the $h r p$-hrc-hpa genes, including hrpD6 but excluding the $h r c C, h r c T, h r p D 5, h r p E$, and hpa3 genes. The leucine-rich protein LrpX (Islam et al. 2009) may negatively regulate certain $h r p$ genes (e.g.,, in $h r p A$ and $h r p E$ operons) indirectly by regulating an as-yet-unidentified repressor for the expression of HrpG and HrpX, which subsequently impacts the expression of hrp-hrc-hpa genes; for example the hrpE gene (Fig. 8). The expression of $h r p X$ but not $h r p G$ is repressed by Zur (Fig. 4), a zinc uptake regulator (Huang et al. 2009), which results in downregulation of the hrp-hrc-hpa genes. The ColR/S twocomponent signal transduction system (Zhang et al. 2008) downregulates the expression of the $h r p X, h r p A$, and hpa 3 operons, whereas Zur positively regulates the expression of the hrpC and hrpE operons in X. campestris pv. campestris (Zhang et al. 2008). Moreover, the expression of $h r c C$, hrpD5, hrpE, and hpa3 may be positively regulated by other unidentified factors, outside of the differential regulation by $\mathrm{HrpG}$, HrpX, Trh, Zur, ColR/S, or LrpX, leading us to assume that some positive regulatory proteins have become negative regu- lators depending on where they bind in unknown promoter regions for $h r c C$, $h r p D 5, h r p E$, and $h p a 3$ gene expression. This possibility is worthy of being scientifically investigated.

\section{MATERIALS AND METHODS}

Bacterial strains, plasmids, and growth conditions.

The bacterial strains used in this study are listed in Table 1 and Supplementary Table S1. Escherichia coli strains were grown in Luria-Bertani medium at $37^{\circ} \mathrm{C}$ (Miller 1972). All $X$. oryzae pv. oryzicola strains were grown in nutrient agar (NA) ( $1 \%$ polypeptone, $0.5 \%$ yeast extract, $1 \%$ sucrose, and $1.5 \%$ agar), NB, NAN (NA without sucrose), or NAS (NA with $10 \%$ sucrose) medium at $28^{\circ} \mathrm{C}$ when required. The $h r p$-inducing medium for $X$. oryzae pv. oryzicola strains is XOM3 (D-Xylose, $1.8 \mathrm{~g} /$ liter; D,L-methionine, $670 \mu \mathrm{M}$; sodium L-glutamate, $10 \mathrm{mM}$; $\mathrm{NaFe}^{2+}$-EDTA, $240 \mu \mathrm{M} ; \mathrm{MgCl}_{2}, 5 \mathrm{mM} ; \mathrm{KH}_{2} \mathrm{PO}_{4}, 14.7$ $\mathrm{mM}$; and $\mathrm{MnSO}_{4}, 40 \mu \mathrm{M}$; pH6.0) (Xiao et al. 2007). Antibiotics were used at the following final concentrations as required: rifampin, $50 \mu \mathrm{g} / \mathrm{ml}$; kanamycin, $25 \mu \mathrm{g} / \mathrm{ml}$; ampicillin, $100 \mu \mathrm{g} / \mathrm{ml}$; and spectinomycin, $50 \mu \mathrm{g} / \mathrm{ml}$.

\section{Recombinant DNA techniques.}

DNA manipulations and PCR were performed according to standard procedures (Sambrook et al. 1989). Mobilization of plasmids into $X$. oryzae pv. oryzicola was performed as de-

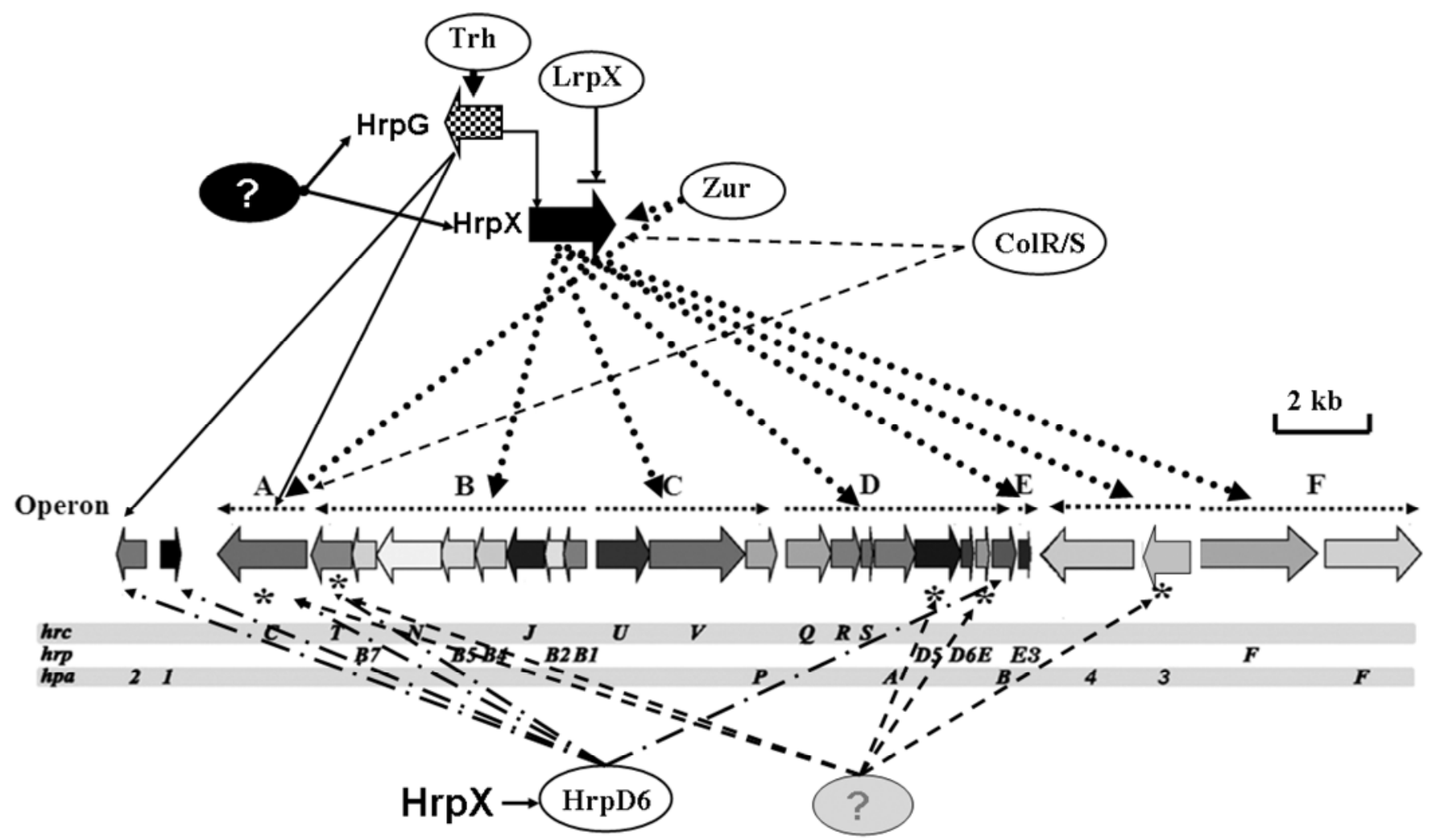

Fig. 8. Working model of hypersensitive response and pathogenicity $(h r p), h r p$-conserved $(h r c), h r p$-associated $(h p a)$ gene cluster ( $h r p$ - $h r c-h p a)$ regulation in Xanthomonas oryzae pv. oryzicola. Horizontal dashed-line arrows indicate the transcriptional units, from the $h r p A$ to $h r p F$ operons, of the $h r p-h r c-h p a$ cluster. Single letters or letters plus numbers or numbers stand for individual $h r p$, $h r c$, and $h p a$ genes beneath the cluster. The $h r p D$ operon consists of eight genes from $h r c Q$ to $h p a B$ and the $h r p E$ operon only contains the $h r p E 3$ gene. Trh positively regulates (black arrow) the expression of $h r p G$. LrpX negatively regulates (black arrow with a stop line) the expression of $h r p X$, which then may lead to higher expression of $h r p E$. Zur significantly represses (dotted line arrows) the expression of $h r p X$, and ColR/S is required (dashed-line arrow) for the expression of the $h r p X$ and $h r p A$ operons. The unknown regulatory factors question-marked with a black oval may regulate (short black arrow) the expression of $h r p G$ and $h r p X$. HrpG positively regulates (long black arrow) the expression of $h r c T$ and $h r p X$. HrpX then activates (dotted-line arrow) the $h r p$ cluster of genes ( $h r p B$ to $h r p F$ operons) except $h r c C$, $h r c T$, $h r p D 5, h r p E$, and $h p a 3$. HrpG also partially controls (long black arrow) the expression of the hpa2 and hrpA operons. Simultaneously, HrpD6, is positively regulated by HrpX, which is activated by HrpG, and can positively control (dashed line arrow) the expression of $h p a l, h p a 2$, and $h p a B$ and partially downregulate the transcription of $h r c C$ and $h r c T$. Genes $h r c C$, $h r c T$, hrpD5, hrpE, and hpa3 are marked with stars to indicate that their expression is HrpG or HrpX independent and may be regulated by one or more other unidentified factors. Ovals with a question mark represent one or more as-yet-uncharacterized regulatory proteins. 
scribed by Turner (2004). Restriction digestion and DNA ligation were performed in accordance with the manufacturer's instructions (Promega, Shanghai, China). Oligonucleotide primers (Table 2) for sequencing or PCR reaction kits were purchased from Jinsite Biotechnology. PCR was performed with $E x$-Taq (Takara Bio Inc., Dalian, China). DNA sequences were analyzed with the VECTOR NTI software package (Infomax; Invitrogen, Shanghai, China).

\section{Rice suspension cell cultures.}

Oryza sativa subsp. indica cv. Shanyou 63, susceptible to $X$. oryzae pv. oryzicola RS105, was used for callus induction. Seed were dehulled and sterilized in $70 \%$ ethanol for $10 \mathrm{~min}, 50 \%$ commercial bleach with a few drops of Tween 20 for $30 \mathrm{~min}$, and then $1 \% \mathrm{HgCl}_{2}$ for $15 \mathrm{~min}$. The sterilized seed were washed five times with sterile distilled water and placed on N6 medium (Chu 1978) with 2,4-D (5 mg/liter) for induction of rice callus in the dark at $28^{\circ} \mathrm{C}$. The actively growing calli were selected and transferred to liquid N6 medium supplemented with 2,4-D at 5 $\mathrm{mg} / \mathrm{liter}$ and kinetin at $1 \mathrm{mg} / \mathrm{liter}$. The cells were maintained in the dark on a 7-day subculture schedule at a dilution of 1:5 (inoculum/fresh medium). Generally, large amounts of rice suspension cells can be obtained after 4 to 5 weeks of subculture and then dispersed, or single round rice cells could be observed under the microscope.

\section{Construction of nonpolar mutants of $X$. oryzae pv. oryzicola RS105.}

According to gene loci referenced in the hrp clusters (AY875714 and AY272885) of X. oryzae pv. oryzicola RS105 (Zou et al. 2006) and in the genome sequence of $X$. oryzae pv. oryzicola BLS256, two pairs of primers, $\phi \mathrm{IF} / \phi \mathrm{IR}$ and $\phi I I F / \phi I I R$ ( $\phi$ represents a target gene) (Table 2$)$, were used to amplify the upstream and downstream fragments flanking the target gene for a two-step integration mutagenesis by using the wild-type RS105 genomic DNA as the template (Table 2). PCR was performed using $E x$-Taq polymerase (Takara Bio Inc.), and the following PCR parameters: step $1,94^{\circ} \mathrm{C}$ for 5 min; step $2,94^{\circ} \mathrm{C}$ for $50 \mathrm{~s}$; step $3,55^{\circ} \mathrm{C}$ for $45 \mathrm{~s}$; step $4,72^{\circ} \mathrm{C}$ for $1 \mathrm{~min} / \mathrm{kb}$; 32 cycles repeating from steps 2 to 4 ; and step 5 , $72^{\circ} \mathrm{C}$ for $7 \mathrm{~min}$. After purification, all PCR products were digested based on restriction sites incorporated into the primer design and cloned into the suicide vector pKMS1 (Jiang et al. 2009 ) to construct the recombinant deletion vector $\mathrm{pKMS} \Delta \phi$ for each gene (Table 1). The expected PCR products were further confirmed by sequencing.

The above deletion vectors $(50 \mathrm{ng} / \mu \mathrm{l})$ were electroporated into competent cells of the RS105 recipient strain and plated for single-colony selection on NAN plates containing kanamycin at 25 $\mu \mathrm{g} / \mathrm{ml}$. Colonies from the initial homologous crossover event which grew on NAN/kanamycin were transferred to NBN broth, grown for $12 \mathrm{~h}$ at $28^{\circ} \mathrm{C}$, and plated on NAS medium. Sucroseresistant colonies were replica streaked onto NA and NA plus kanamycin plates. Recombinants resulting from double crossover events were selected by $s a c B$ and sucrose-positive selection. Mutations were confirmed by PCR amplification with pair primers $(\phi I F / \phi I I R)$. Subsequent Southern hybridization (digoxigenin; Roche, Mannheim, Germany) was conducted to verify the deletion of the target genes. One of the confirmed deletion colonies (Table 1) was used for further study.

\section{Complementation of mutants.}

To sort out the text, some of the complementation constructs were listed in the main text (Table 1) and others in the supplementary material. Complementations were confirmed by restoration of pathogenicity or virulence in rice and $\mathrm{HR}$ in tobacco to wild-type levels (data not shown). Mutants were comple- mented with the corresponding 27 hrp-hrc-hpa genes driven by their respective operon promoters of the core $h r p$ cluster (Table 1) and the seven regulatory genes $h r p G, h r p X, t r h, \operatorname{lrpX}$, $z u r$, and $c o l R / S$, driven by their native promoters. For complementation of the hrpD6 mutant R $\Delta h r p D 6$, a 243-bp DNA fragment containing the entire hrpD6 coding region was amplified by PCR with primers $h r p D 6 \mathrm{~F}$ and $h r p D 6 \mathrm{R}$ using the genomic DNA of strain RS105 as a template. Correspondingly, a 370-bp hrpD operon promoter was amplified by PCR using primers phrpD51F and phrpD51R (Table 2). After confirmation by sequencing, the amplified DNA fragments were cloned into pUFR034 to create the recombinant plasmid pChrpD6 (Table 1). The recombinant plasmid was transferred into $\mathrm{R} \Delta h r p D 6$ by electroporation. Transconjugants carrying pChrpD6 were selected on NA plates containing kanamycin, and one representative complementation strain (CR $\Delta h r p D 6)$ was verified by colony PCR and chosen for further study (Table 1).

\section{Pathogenicity and HR assays.}

Hrp assays were performed as described (Zou et al. 2006). $X$. oryzae pv. oryzicola strains were assessed for their ability to cause disease symptoms and multiply in rice IR24 plants by inoculation of rice seedling leaves ( 2 weeks old) by infiltration with needleless syringes and adult rice ( 2 months old) by the leaf needling method, with bacterial suspensions adjusted to $1 \times$ $10^{8} \mathrm{CFU} / \mathrm{ml}$. The strains were also tested for the ability to elicit an HR on Nicotiana benthamiana by infiltration of plant tissue with strains adjusted to $1 \times 10^{8} \mathrm{CFU} / \mathrm{ml}$ with a needleless syringe. Plant responses were scored for HR in tobacco 24 $\mathrm{h}$ postinoculation, for water soaking in rice seedlings 3 days postinoculation (dpi), and after $14 \mathrm{dpi}$ for lesion lengths. All plants were grown in growth chambers at $25^{\circ} \mathrm{C}$ with a $12-\mathrm{h}$ photoperiod. Experiments were repeated at least three times.

\section{Semiquantitative RT-PCR analysis.}

Single colonies of $X$. oryzae pv. oryzicola RS105 and deletion mutants were inoculated into $20 \mathrm{ml}$ of $\mathrm{NB}$ broth and grown at $28^{\circ} \mathrm{C}$ for 24 to $36 \mathrm{~h}$ until the optical density at $600 \mathrm{~nm}\left(\mathrm{OD}_{600}\right)$ value reached 0.8 . This culture $(2 \mathrm{ml})$ was subcultured into 100 $\mathrm{ml}$ of fresh NB and incubated for another 12 to $16 \mathrm{~h}$ until the $\mathrm{OD}_{600}$ reached 0.6. After centrifugation at $6,000 \mathrm{rpm}$ for $10 \mathrm{~min}$ at $4^{\circ} \mathrm{C}$, the pellet was washed in sterilized water twice and each wash followed by centrifugation for $10 \mathrm{~min}$. The pellet was eventually resuspended in sterilized water to $\mathrm{OD}_{600}=2.0$. Then, $40 \mu \mathrm{l}$ of this bacterial suspension was inoculated into $1 \mathrm{ml}$ of rice suspension cells. After incubation for $16 \mathrm{~h}$ at $26^{\circ} \mathrm{C}$, bacteria were collected by centrifugation at $12,000 \mathrm{rpm}$ for $5 \mathrm{~min}$ and total RNA was extracted using the Trizol method (Invitrogen). The extracted RNA was treated with DNase I (Takara Bio Inc.) and purified. The RNA was then used as the template for PCR amplification of $27 h r p-h r c-h p a$ genes with primers to ensure that RNA samples contained no contaminating genomic DNA. Total RNA $(2 \mu \mathrm{g})$ was used to synthesize cDNA using the RNA PCR kit (AMV) with random primers (order number D3801) provided by the manufacturer (Takara Bio Inc.). The reaction was performed at $30^{\circ} \mathrm{C}$ for $10 \mathrm{~min}, 42^{\circ} \mathrm{C}$ for $1 \mathrm{~h}$, and inactivated at $75^{\circ} \mathrm{C}$ for $5 \mathrm{~min}$. The cDNA product $(1 \mu \mathrm{l})$ and gene-specific primers (Table 3 ) were used in the RT-PCR reaction with the following PCR program: step $1,95^{\circ} \mathrm{C}$ for $5 \mathrm{~min}$; step $2,95^{\circ} \mathrm{C}$ for $50 \mathrm{~s}$; step $3,53^{\circ} \mathrm{C}$ for $30 \mathrm{~s}$; step $4,72^{\circ} \mathrm{C}$ for $40 \mathrm{~s} ; 35$ cycles repeating from steps 2 to 4 ; and step $5,72^{\circ} \mathrm{C}$ for $7 \mathrm{~min}$. The RT$\mathrm{PCR}$ products were sequenced to confirm specificity of the primers for the hrp-hrc-hpa genes.

\section{Northern blot assay.}

After induction in rice suspension cells, total RNA was extracted from $X$. oryzae pv. oryzicola strains as described above 
at the indicated time point. For each sample, $30 \mu \mathrm{g}$ of total RNA was subjected to electrophoresis in $1 \%$ agarose gels. The Biotin-labeled DNA probe was prepared by the BrightStar Psoralen-Biotin Labeling kit (Ambion, Austin, TX, U.S.A.) according to the manufacturer's instructions. The RNA was transferred to Hybond $\mathrm{N}^{+}$positively charged nylon membrane (Amersham Pharmacia, Uppsala, Sweden) and hybridized with specific probes at $42^{\circ} \mathrm{C}$ using Northern Max (Ambion), and signals were detected using BrightStar BioDetect (Ambion) according to the manufacturer's instructions.

\section{GUS activity assay.}

To construct hrp promoter-GUS fusion constructs, the promoter regions of target genes in this study were fused to the promoterless gusA gene (Mitsuhara et al. 1996) with its ribosome binding site. Regions upstream of the start codon of these genes were amplified by PCR using the total DNA of the wild-type strain RS105 as the template, with primer pairs phrcCF/phrcCR, phrpD51F/phrpD51R, phrpD52F/phrpD52R, phpa3F/phpa3R, phrcT1F/phrcT1R, phpalF/phpalR, phrpGF/ phrpGR, and phrpXF/phrpXR (Table 2) and fused to gusA, which was amplified with primer pair gus $\mathrm{F} / g u s \mathrm{R}$ (Table 2). Promoter-gusA fusions were cloned into pUFR034 (De Feyter et al. 1990) with EcoRI, giving phrcCGUS, phrpD51GUS, phrpD52GUS, phpa3GUS, phrcT1GUS, phrcT2GUS, phpa1GUS, phrpGGUS, and phrpXGUS (Table 1).

To investigate whether HrpD6 regulates hpal expression, HrpD6 was expressed in the $h r p X$ mutant R $\Delta h r p X$ by using the constitutive promoter of a $X$. oryzae pv. oryzicola RS105 extracellular protease gene (Xoryp_01688) to drive hrpD6 expression, while the hpal::gusA reporter was used as an indicator. Xoryp_01688 is $100 \%$ identical to Xoryp_01688 of X. oryzae pv. oryzicola BLS256, which we proved to have extracellular protease activity (unpublished data). A 466-bp promoter upstream of Xoryp_01688 and a 243-bp ORF of hrpD6 ending with a stop codon were amplified by PCR using the genomic DNA of the wild-type RS105 as the template, with primer pairs pecpAF/pecpAR and hrpD6F1/hrpD6R1 (Table 2), respectively. The Xoryp_01688 promoter region and hrpD6 ORF were fused together at a BamHI site and subsequently fused at a $K p n I$ site to a 2,044-bp hpal promoter-GUS fusion, which was amplified from phpalGUS with primer pair phpa1GUSF/phpa1GUSR (Table 2). The entire 2,753-bp fusion was later cloned into pUFR034 at an EcoRI site, giving plasmid pD6hpa1GUS (Table 1).

For GUS activity assays, X. oryzae pv. oryzicola strains were cultured in $\mathrm{XOM} 3$ to $\mathrm{OD}_{600}=0.5$. Bacteria cells were diluted and disrupted in sonic buffer $(20 \mathrm{mM}$ Tris- $\mathrm{HCl}, \mathrm{pH}$ 7.0; $10 \mathrm{mM}$ 2-mercaptoethanol; $5 \mathrm{mM}$ EDTA; and 1\% Triton $\mathrm{X}-100)$. GUS activities were determined at intervals of $15 \mathrm{~min}$ until $4 \mathrm{~h}$ by measurement of the $\mathrm{OD}_{415}$ using PNPG as the substrate (Jefferson et al. 1987). One unit (U) was defined as 1 nmol of 4-methyl-umbelliferone produced per minute per bacterium.

\section{Type III secretion assays.}

To generate Hpa2-c-Myc, Hpa1-c-Myc, and HrpF-c-Myc expression constructs, hpa2 with the promoter region ( -216 to -1 bp upstream), hpal with the promoter region ( -231 to -1 bp upstream), and $h r p F$ with the promoter region (-667 to -1 bp upstream), respectively, were amplified from the genomic DNA of $X$. oryzae pv. oryzicola RS105 strain by PCR with the primers listed in Table 2. The PCR products were cloned into corresponding restriction sites of pHM1 in-frame with a c-Myc epitope-encoding sequence, giving pHpa2-c-Myc, pHpa1-cMyc, and pHrpF-c-Myc (Table 2), respectively. The AvrXa27Flag in the pHM1 vector has previously been used in $X$. oryzae pv. oryzae for detection of proteins secreted through the T3S apparatus ( $\mathrm{Gu}$ et al. 2005). These constructs were then transformed individually into the wild-type strain RS105, the $h r c V$ mutant $\mathrm{R} \Delta h r c V$, the $h r p D 6$ mutant R $\Delta h r p D 6$, and the $h p a B$ mutant R $\Delta h p a B$ (Table 1), respectively, for protein secretion detection.

For Western blot analysis, X. oryzae pv. oryzicola strains were preincubated in $\mathrm{NB}$ medium, resuspended at $\mathrm{OD}_{600}=2.0$ in sterilized water, and washed twice. Then, $40 \mu \mathrm{l}$ of the bacterial suspension was inoculated into $1 \mathrm{ml}$ of the $h r p$-inducing medium XOM3 (pH 6.5) at $28^{\circ} \mathrm{C}$ for $16 \mathrm{~h}$. Cell and supernatant fractions were separated by centrifugation, and proteins in the supernatant fraction were precipitated with $12.5 \%$ trichloroacetic acid (Laemmli 1970). Proteins were separated on $10 \%$ sodium dodecyl sulfate polyacrylamide gel electrophoresis gels and transferred to membranes for immunoblotting using primary antibody anti-FLAG or anti-c-Myc (Genescript, Nanjing, China). Primary antibodies were recognized by antirabbit secondary antibodies (Genescript) and visualized on autoradiographs with the Western-Light chemiluminescence system (Transgene, Nanjing, China).

\section{ACKNOWLEDGMENTS}

We thank A. Collmer at Cornell University for his critical suggestions and helpful discussions on the manuscript when G.-Y. Chen worked in his lab as a Tang Scholar. This work was supported by the State Key Basic Research and Development Project of China, the Natural Science Foundation of China (30710103902, 31071656) and the Special Fund for Agroscientific Research in the Public Interest of China (NYHYZX07-056, 201003067-09)

\section{LITERATURE CITED}

Alfano, J. R., and Collmer, A. 1997. The type III (Hrp) secretion pathway of plant pathogenic bacteria: Trafficking harpins, Avr proteins, and death. J. Bacteriol. 179:5655-5662.

Arlat, M., Gough, C. L., Barber, C. E., Boucher, C., and Daniels, M. J. 1991. Xanthomonas campestris contains a cluster of hrp genes related to the larger hrp cluster of Pseudomonas solanacearum. Mol. PlantMicrobe Interact. 4:593-601.

Astua-Monge, G., Freitas-Astua, J., Bacocina, G., Roncoletta, J., Carvalho, S. A., and Machado, M. A. 2005. Expression profiling of virulence and pathogenicity genes of Xanthomonas axonopodis pv. citri. J. Bacteriol. 187:1201-1205.

Bonas, U. 1994. hrp Genes of phytopathogenic bacteria. Curr. Top. Microbiol. Immunol. 192:79-98.

Bonas, U., Schulte, R., Fenselau, S., Minsavage, G. V., Staskawicz, B. J., and Stall, R. E. 1991. Isolation of a gene-cluster from Xanthomonas campestris pv. vesicatoria that determines pathogenicity and the hypersensitive response on pepper and tomato. Mol. Plant-Microbe Interact. 4:81-88.

Brito, B., Marenda, M., Barberis, P., Boucher, C., and Genin, S. 1999. prhJ and $h r p G$, two new components of the plant signal-dependent regulatory cascade controlled by PrhA in Ralstonia solanacearum. Mol. Microbiol. 31:237-251.

Büttner, D., and Bonas, U. 2002. Getting across-bacterial type III effector proteins on their way to the plant cell. EMBO (Eur. Mol. Biol. Organ.) J. 21:5313-5322.

Büttner, D., and Bonas, U. 2006. Who comes first? How plant pathogenic bacteria orchestrate type III secretion. Curr. Opin. Microbiol. 9:193-200.

Büttner, D., and Bonas, U. 2010. Regulation and secretion of Xanthomonas virulence factors. FEMS (Fed. Eur. Microbiol. Soc.) Microbiol. Lett. 34:107-133.

Büttner, D., Noël, L., Thieme, F., and Bonas, U. 2003. Genomic approaches in Xanthomonas campestris pv. vesicatoria allow fishing for virulence genes. J. Biotechnol. 106:203-214.

Büttner, D., Gürlebeck, D., Noël, L. D., and Bonas, U. 2004. HpaB from Xanthomonas campestris pv. vesicatoria acts as an exit control protein in type III-dependent protein secretion. Mol. Microbiol. 54:755-768.

Büttner, D., Lorenz, C., Weber, E., and Bonas, U. 2006. Targeting of two effector protein classes to the type III secretion system by a HpaC- and HpaB-dependent protein complex from Xanthomonas campestris pv. vesicatoria. Mol. Microbiol. 59:513-527.

Büttner, D., Noël, L., Stuttmann, J., and Bonas, U. 2007. Characterization 
of the nonconserved $h p a B-h r p F$ region in the $h r p$ pathogenicity island from Xanthomonas campestris pv. vesicatoria. Mol. Plant-Microbe Interact. 20:1063-1074.

Cho, H. J., Park, Y. J., Noh, T. H., Kim, Y. T., Kim, J. G., Song, E. S., Lee, D. H., and Lee, B. M. 2008. Molecular analysis of the hrp gene cluster in Xanthomonas oryzae pathovar oryzae KACC10859. Microb. Pathog. 44:473-483

Chu, C. C. 1978. The N6 medium and its application to anther culture of cereal crops. Pages:43-50 in: Proc. Symp. Plant Tissue Culture. Science Press, Beijing.

Cunnac, S., Lindeberg, M., and Collmer, A. 2009. Pseudomonas syringae type III secretion system effectors: Repertoires in search of functions. Curr. Opin. Microbiol. 12:53-60.

De Feyter, R., Kado, C. I., and Gabriel, D. W. 1990. Small, stable shuttle vectors for use in Xanthomonas. Gene 88:65-72.

Deng, W. L., and Huang, H. C. 1999. Cellular locations of Pseudomonas syringae pv. syringae $\mathrm{HrcC}$ and $\mathrm{HrcJ}$ proteins, required for harpin secretion via the type III pathway. J. Bacteriol. 181:2298-2301.

Feng, J. X., Song, Z. Z., Duan, C. J., Zhao, S., Wu, Y. Q., Wang, C., Dow, J. M., and Tang, J. L. 2009. The xrvA gene of Xanthomonas oryzae pv. oryzae, encoding an $\mathrm{H}-\mathrm{NS}$-like protein, regulates virulence in rice. $\mathrm{Mi}$ crobiology 155:3033-3044.

Furutani, A., Nakayama, T., and Ochiai, H. 2006. Identification of novel HrpXo regulons preceded by two cis-acting elements, a plant-inducible promoter box and a -10 box-like sequence, from the genome database of Xanthomonas oryzae pv. oryzae. FEMS (Fed. Eur. Microbiol. Soc.) Microbiol. Lett. 259:133-141.

Furutani, A., Takaoka, M., Sanada, H., Noguchi, Y., Oku, T., Tsuno, K., Ochiai, H., and Tsuge S. 2009. Identification of novel type III secretion effectors in Xanthomonas oryzae pv. oryzae. Mol. Plant-Microbe Interact. 22:96-106

Gu, K. Y., Yang, B., Tian, D. S., Wu, L. F., Wang, D. J., Sreekala, C., Yang, F., Chu, Z. Q., Wang, G. L., White, F. F., and Yin, Z. C. 2005. $R$ gene expression induced by a type-III effector triggers disease resistance in rice. Nature 435:1122-1125

Guo, X. X., Zou, H. S., Li, Y. R., Zou, L. F., and Chen, G. Y. 2010. hrpD6 gene determines Xanthomonas oryzae pv. oryzae to trigger hypersensitive response in tobacco and pathogenicity in rice. Acta Microbiol. Sin. 50:1155-1163.

Gürlebeck, D., Thieme, F., and Bonas, U. 2006. Type III effector proteins from the plant pathogen Xanthomonas and their role in the interaction with the host plant. J. Plant Physiol. 163:233-255.

He, S. Y. 1998. Type III protein secretion system in plant and animal pathogenic bacteria. Annu. Rev Phytopathol. 36:363-392.

Huang, D. L., Tang, D. J., Liao, Q., Li, X. Q., He, Y. Q., Feng, J. X., Jiang, B. L., Lu, G. T., and Tang, J. L. 2009. The Zur of Xanthomonas campestris is involved in hypersensitive response and positively regulates the expression of the $h r p$ cluster via $h r p X$ but not $h r p G$. Mol. PlantMicrobe Interact. 22:321-329.

Hueck, C. J. 1998. Type III protein secretion systems in bacterial pathogens of animals and plants. Microbiol. Mol. Biol. 62:379-433.

Islam, M. R., Kabir, M. S., Hirata, H., Tsuge, S., and Tsuyumu, S. 2009. A leucine-rich protein, LrpX, is a new regulator of hrp genes in Xanthomonas oryzae pv. oryzae. J. Gen. Plant Pathol. 75:66-71.

Jefferson, R. A., Kavanagh, T. A., and Bevan, M. W. 1987. GUS fusions: Beta-glucuronidase as a sensitive and versatile gene fusion marker in higher plants. EMBO (Eur. Mol. Biol. Organ.) J. 6:3901-3907.

Jiang, J., Zou, H. S., Li, Y. R., and Chen, G. Y. 2009. Expression of the $h r c C$, hrpE and hpa3 genes is not regulated by the $h r p G$ and $h r p X$ genes in a rice pathogen Xanthomonas oryzae pv. oryzicola. Acta Microbiol. Sin. 49:1018-1025.

Kamdar, H. V., Kamoun, S., and Kado, C. I. 1993. Restoration of pathogenicity of avirulent Xanthomonas oryzae pv. oryzae and $X$. campestris pathovars by reciprocal complementation with the hrpXo and $h r p X c$ genes and identification of HrpX function by sequence analyses. J. Bacteriol. 175:2017-2025.

Kim, J. F., We, Z. M., and Beer, S. V. 1997. The hrpA and $h r p C$ operons of Erwinia amylovora encode components of a type III pathway that secretes harpin. J. Bacteriol. 179:1690-1697.

Kim, J. G., Park, B. K., Yoo, C. H., Jeon, E., Oh, J., and Hwang, I. 2003. Characterization of the Xanthomonas axonopodis pv. glycines Hrp pathogenicity island. J. Bacteriol. 185:3155-3166.

Koebnik, R., Kruger, A., Thieme, F., Urban, A., and Bonas U. 2006. Specific binging of the Xanthomonas campertris pv. vesicatoria AraC-type transcriptional activator $\operatorname{HrpX}$ to plant-inducible promoter boxes. J. Bacteriol. 188:7652-7660.

Kubori, T., Matsushima, Y., Nakamura, D., Uralil, J., Lara-Tejero, M., Sukhan, A., Galán, J. E., and Aizawa, S. I. 1998. Supramolecular structure of the Salmonella typhimurium type III protein secretion system. Science 280:602-605
Laemmli, U. K. 1970. Cleavage of structural proteins during the assembly of the head of bacteriophage T4. Nature 227:680-685.

Lee, B. M., Park, Y. J., Park, D. S., Kang, H. W., Kim, J. G., Song, E. S., Park, I. C., Yoon, U. H., Hahn, J. H., Koo, B. S., Lee, G. B., Kim, H Park, H. S., Yoon, K. O., Kim, J. H., Jung, C. H., Koh, N. H., Seo, J. S., and Go, S. J. 2005. The genome sequence of Xanthomonas oryzae pathovar oryzae KACC10331, the bacterial blight pathogen of rice. Nucleic Acids Res. 33:577-586.

Lee, S. W., Jeong, K. S., Han, S. W., Lee, S. E., Phee, B. K., Hahn, T. R. and Ronald, P. 2008. The Xanthomonas oryzae pv. oryzae PhoP/Q twocomponent system is required for AvrXA21 activity, hrpG expression, and virulence. J. Bacteriol. 190:2183-2197.

Miller, J. H. 1972. Experiments in Molecular Genetics. Cold Spring Harbor Laboratory Press, Cold Spring Harbor, NY, U.S.A.

Mitsuhara, I., Ugaki, M., Hirochika, H., Ohshima, M., Murakami, T., Gotoh, Y., Katayose, Y., Nakamura, S., Honkura, R., Nishimiya, S., Ueno, K., Mochizuki, A., Tanimoto, H., Tsugawa, H., Otsuki, Y., and Ohashi, Y. 1996. Efficient promoter cassettes for enhanced expression of foreign genes in dicotyledonous and monocotyledonous plants. Plant Cell Physiol. 37:49-59.

Niño-Liu, D. R., and Bogdanove, A. J. 2006. Xanthomonas oryzae pathovars: Model pathogens of a model crop. Mol. Plant Pathol. 7:303324.

Ochiai, H., Inoue, Y., Takeya, M., Sasaki, A., and Kaku, H. 2005. Genome sequence of Xanthomonas oryzae pv. oryzae suggests contribution of large numbers of effector genes and insertion sequences to its race diversity. JARQ (Jpn. Agric. R. Q.). 39:275-287.

Oku, T., Alvarez, A. M., and Kado, C. I. 1995. Conservation of the hypersensitivity-pathogenicity regulatory gene hrpX of Xanthomonas campestris and $X$. oryzae. DNA Seq. 5:245-249.

Ortiz-Martín, I., Thwaites, R., Mansfield, J. W., and Beuzón, C. R. 2010a. Negative regulation of the Hrp type III secretion system in Pseudomo nas syringae pv. phaseolicola. Mol. Plant-Microbe Interact. 23:682701.

Ortiz-Martín, I., Thwaites, R., Mansfield, J. W., and Beuzón, C. R. 2010b. Positive regulation of the Hrp type III secretion system in Pseudomonas syringae pv. phaseolicola. Mol. Plant-Microbe Interact. 23:665-681.

Pallen, M. J., Beatson, S. A., and Bailey, C. M. 2005. Bioinformatics, genomics and evolution of non-flagellar type-III secretion systems: A Darwinian perspective. FEMS (Fed. Eur. Microbiol. Soc.) Microbiol. Lett. 29:201-229.

Rossier, O., Van den Ackerveken, G., and Bonas, U. 2000. HrpB2 and HrpF from Xanthomonas are type III-secreted proteins and essential for pathogenicity and recognition by the host plant. Mol. Microbiol. 38:828-838.

Salzberg, S. L., Sommer, D. D., Schatz, M. C., Phillippy, A. M., Rabinowicz, P. D., Tsuge, S., Furutani, A., Ochiai, H., Delcher, A. L., Kelley, D., Madupu, R., Puiu, D., Radune, D., Shumway, M., Trapnell, C., Aparna, G., Jha, G., Pandey, A., Patil, P. B., Ishihara, H., Meyer, D. F., Szurek, B., Verdier, V., Koebnik, R., Dow, J. M., Ryan, R. P., Hirata, H., Tsuyumu, S., Won Lee, S., Seo, Y S., Sriariyanum, M., Ronald, P. C., Sonti, R. V., Van Sluys, M. A., Leach, J. E., White, F. F., and Bogdanove, A. J. 2008. Genome sequence and rapid evolution of the rice pathogen Xanthomonas oryzae pv. oryzae PXO99 ${ }^{\mathrm{A}}$. BMC Genomics 9:204.

Sambrook, J., Fritsch, E. F., and Maniatis, T. 1989. Molecular Cloning: A Laboratory Manual. Cold Spring Harbor Laboratory Press, Cold Spring Harbor, NY, U.S.A

Schulte, R., and Bonas, U. 1992. A Xanthomonas pathogenicity locus is induced by sucrose and sulfur-containing amino acid. Plant Cell 4:7986

Seo, Y. S., Sriariyanun, M., Wang, L., Pfeiff, J., Phetsom, J., Lin, Y., Jung, K. H., Chou, H. H., Bogdanove, A. J., and Ronald, P. 2008. A twogenome microarray for the rice pathogens Xanthomonas oryzae pv. oryzae and $X$. oryzae pv. oryzicola and its use in the discovery of a difference in their regulation of hrp genes. BMC Microbiol. 8:99.

Sugio, A., Yang, B., and White, F. F. 2005. Characterization of the hrpF pathogenicity peninsula of Xanthomonas oryzae pv. oryzae. Mol. PlantMicrobe Interact. 18:546-554.

Tang, D. J., Li, X. J., He, Y. Q., Feng, J. X., Chen, B., and Tang, J. L. 2005. The zinc uptake regulator Zur is essential for the full virulence of Xanthomonas campestris pv. campestris. Mol. Plant-Microbe Interact. 18:652-658.

Tang, X. Y., Xiao, Y., and Zhou, J. M. 2006. Regulation of the type III secretion system in phytopathogenic bacteria. Mol. Plant-Microbe Interact. 19:1159-1166.

Tsuge, S., Furutani, A., Kubo, Y., and Horino, O. 2001. Identification of a $\mathrm{H}+$ glucose and galactose symporter gene glt from Xanthomonas oryzae pv. oryzae. Microbiol. Immunol. 45:543-547.

Tsuge, S., Nakayama, T., Terashima, S., Ochiai, H., Furutani, A., Oku, T. 
Tsuno, K., Kubo, Y., and Kaku, H. 2006. Gene involved in transcriptional activation of the hrp regulatory gene hrpG in Xanthomonas oryzae pv. oryzae. J. Bacteriol. 188:4158-4162.

Turner, P. E. 2004. Phenotypic plasticity in bacterial plasmids. Genetics 167:9-20.

Wang, Y. P., Zou, L. F., Zhou, D., and Chen, G. Y. 2009. Key roles of hrpE gene of Xanthomonas oryzae pv. oryzicola in formation of Hrp pilus and pathogenicity in rice. Acta Phytopathol. Sin. 39:392-398.

Weber, E., and Koebnik, R. 2005. Domain Structure of HrpE, the Hrp Pilus Subunit of Xanthomonas campestris pv. vesicatoria. J. Bacteriol. 187:6175-6186.

Weber, E., Ojanen-Reuhs, T., Huguet, E., Hause, G., Romantschuk, M. Korhonen, T. K., Bonas, U., and Koebnik, R. 2005. The type III-dependent Hrp pilus is required for productive interaction of Xanthomonas campestris pv. vesicatoria with pepper host plants. J. Bacteriol. 187:458-468.

Weber, E., Berger, C., Bonas, U., and Koebnik, R. 2007. Refinement of the Xanthomonas campestris pv. vesicatoria hrpD and hrpE operon structure. Mol. Plant-Microbe Interact. 20:559-567.

Wei, Z., Kim, J. F., and Beer, S. V. 2000. Regulation of hrp genes and type III protein secretion in Erwinia amylovora by HrpX/HrpY, a novel twocomponent system, and HrpS. Mol. Plant-Microbe Interact. 13:12511262

Wengelnik, K., and Bonas, U. 1996. HrpXv, an AraC-type regulator, activates expression of five of the six loci in the hrp cluster of Xanthomonas campestris pv. vesicatoria. J. Bacteriol. 178:3462-3469.

Wengelnik, K., Marie, C., Russel, M., and Bonas, U. 1996a. Expression and localization of HrpA1, a protein of Xanthomonas campestris pv. vesicatoria essential for pathogenicity and induction of the hypersensitive reaction. J. Bacteriol. 178:1061-1069.

Wengelnik, K., Van den Ackerveken, G., and Bonas, U. 1996b. HrpG, a key hrp regulatory protein of Xanthomonas campestris pv. vesicatoria is homologous to two-component response regulators. Mol. Plant-Microbe Interact. 9:704-712.

Wengelnik, K., Rossier, O., and Bonas, U. 1999. Mutations in the regulatory gene hrpG of Xanthomonas campestris pv. vesicatoria result in constitutive expression of all hrp genes. J. Bacteriol. 181:6828-6831.

Xiao, Y. L., Li, Y. R., Liu, Z. Y., Xiang, Y., and Chen, G. Y. 2007. Establishment of the hrp-inducing systems for the expression of the hrp genes of Xanthomonas oryzae pv. oryzicola. Acta Microbiol. Sin. 47:396-401.

Xiao, Y., Lu, Y., Heu, S., and Hutcheson, S. W. 1992. Organization and environmental regulation of the Pseudomonas syringae pv. syringae 61 hrp cluster. J. Bacteriol. 174:1734-1741.

Yang, W., Liu, Y., Chen, L., Gao, T., Hu, B., Zhang D., and Liu, F. 2007. Zinc uptake regulator (zur) gene involved in zinc homeostasis and virulence of Xanthomonas oryzae pv. oryzae in rice. Curr. Microbiol. 54:307-314.

Zhang, S. S., He, Y. Q., Xu, L. M., Chen, B. W., Jiang, B. L., Liao, J., Cao, J. R., Liu, D., Huang, Y. Q., Liang, X. X., Tang, D. J., Lu, G. T., and Tang J. L. 2008. A putative colR (XC1049)-colS (XC1050) two-component signal transduction system in Xanthomonas campestris positively regulates $h r p C$ and $h r p E$ operons and is involved in virulence, the hypersensitive response and tolerance to various stresses. Res. Microbiol. 159:569-578.

Zou, L. F., Wang, X. P., Xiang, Y., Zhang, B., Li, Y. R., Xiao, Y. L., Wang, J. S., Walmsley, A. R., and Chen, G. Y. 2006. Elucidation of the hrp clusters of Xanthomonas oryzae pv. oryzicola that control the hypersensitive response in nonhost tobacco and pathogenicity in susceptible host rice. Appl. Environ. Microbiol. 72:6212-6224.

\section{AUTHOR-RECOMMENDED INTERNET RESOURCES}

Berkeley Drosophila Genome Project website: www.fruitfly.org/seq_tools/promoter.html

NCBI Nucleotide Alphabet of Life website: www.ncbi.nlm.nih.gov/nuccore/NZ_AAQN01000001

Jinsite Biotechnology website:

www.croasia.net/company/jinsite_biotechnology_co.html

Takara Bio Inc. website: www.takara-bio.com

Life Technologies Invitrogen website: www.invitrogen.com 